\title{
Trends in the Application of Permeable Pavement as Sustainable Highway Storm Water Management Option for Safe-Use of Roadways
}

\section{Dr. Udeme J Ndon*}

Department of Civil and Environmental Engineering, San Jose State University, San Jose, CA 95192-0083, USA

\begin{abstract}
Accumulation of storm water on road surfaces and the associated runoff result in environmental pollution problems, negative impact on durability of pavement and safety problems for the travelling public. Permeable pavement has been used to reduce imperviousness of paved surfaces and storm water runoff due to the presence of pores through which water passes into underneath layer of the pavement where the water is collected for treatment prior to discharge into the environment. As a result, permeable pavement is seen as an environmentally sustainable system. Although permeable pavement was initially developed for foot and bicycle traffic, because of sustainability benefits it provides, there is growing interest in advancing the use of permeable pavement in highway storm water management. This article presents trends in the application of permeable pavement in highway storm water management and some associated highway safety benefits.
\end{abstract}

Keywords: Pavers; Permeable pavement; Pervious concrete; Porous asphalt; Sustainable highway storm water management

\section{Introduction}

Urbanization has resulted in the replacement of pervious vegetative lands by impervious surfaces, such as pavement, which reduces the area where infiltration to groundwater can occur. This has resulted in accumulation of storm water on road surface, runoff into streams and possibly leading to flooding.

Removal of storm water from road surfaces became essential to: protect pavements from water-induced damage, reduce road accidents associated splash and spray of road water, reduce road accidents associated with reduced friction coefficient (skid resistance) caused by road water, and reduce road accidents associated with hydroplaning caused by road water. Therefore, storm water removal from impervious road surfaces became an integral component of highway design that is commonly achieved by extensive drainage systems that include sloping raod surfaces in combination with curbs, ditches and storm sewer.

Later on, it became known that motor vehicles do deposit various pollutants on roads and parking lots such as chemicals that are present in automobile lubrication oils, gasoline, antifreeze, tire wear, particulates coming from exhaust system, and automobile braking system. During rain fall events, these pollutants are washed from the road surface and are carried by the storm water runoff into soils, groundwater and surface water. The constituents and sources of pollutants in highway runoff as well as typical concentrations of the pollutants have been reported by the Federal Highway Administration [1] and are presented in Tables 1 and 2. As documented by Walsh et al. [2], urban storm water runoff has become a new class of environmental flow problem. Figure 1 presents an illustration of various sources of contaminants in road environments, including storm water runoffs from roads.

With the presence of pollutants in storm water runoff, transportation agencies in the country are required by Environmental Protection Agency (U.S. EPA) to comply with the National Pollution Discharge Elimination Standard (NPDES) including planning and design permit requirements for the treatment of storm water runoff. The compliance requirement is to ensure that rainwater runoff from roads including local, states, and federal roads do not carry pollutants into waterways such as rivers, creeks, lakes, and streams.

According to U.S. Environmental Protection Agency [3], transportation authorities are responsible for managing storm water runoff that discharges to the nation's waters through regulated municipal

\begin{tabular}{|c|c|}
\hline Constituents & Sources \\
\hline Particulates & $\begin{array}{c}\text { Pavement wear, vehicles, atmospheric deposition, } \\
\text { maintenance activities }\end{array}$ \\
\hline Nitrogen, Phosphorus & Atmospheric deposition and fertilizer application \\
\hline Lead & Leaded gasoline from auto exhausts and tire wear \\
\hline Zinc & Tire wear, motor oil, and grease \\
\hline Iron & $\begin{array}{c}\text { Auto body rust, steel highway structures such as bridges } \\
\text { and guardrails, and moving engine parts }\end{array}$ \\
\hline Copper & $\begin{array}{l}\text { Metal plating, bearing and brushing wear, moving engine } \\
\text { parts, brake lining wear, fungicides and insecticides }\end{array}$ \\
\hline Cadmium & Tire wear and insecticide application \\
\hline Chromium & Metal plating, moving engine parts, and brake lining wear \\
\hline Nickel & $\begin{array}{l}\text { Diesel fuel and gasoline, lubricating oil, metal plating, } \\
\text { brushing wear, brake lining wear, and asphalt paving }\end{array}$ \\
\hline Manganese & Moving engine parts \\
\hline Cyanide & $\begin{array}{l}\text { Anti-caking compounds used to keep deicing salts } \\
\text { granular }\end{array}$ \\
\hline $\begin{array}{l}\text { Sodium, Calcium, } \\
\text { Chloride }\end{array}$ & Deicing salts \\
\hline Sulphates & Roadway beds, fuel, and deicing salts \\
\hline Petroleum & $\begin{array}{l}\text { Sprill, leaks, antifreeze and hydraulic fluids, and asphalt } \\
\text { surface leachate }\end{array}$ \\
\hline
\end{tabular}

Table 1: Constituents and sources of pollutants in highway runoff [1].

\begin{tabular}{|c|c|}
\hline Parameters & Concentration $\mathbf{( m g / L )}$ \\
\hline Total Suspended Solids (TSS) & $45-798$ \\
\hline Volatile Suspended Solids (VSS) & $4.3-79$ \\
\hline Total Organic Carbon (TOC) & $24-77$ \\
\hline Chemical Oxygen Demand (COD) & $14.7-272$ \\
\hline Biochemical Oxygen Demand (BOD) & $12.7-37$ \\
\hline Nitrate+Nitrite $\left(\mathrm{NO}_{3}+\mathrm{NO}_{2}\right)$ & $0.15-1.636$ \\
\hline Total Kjeldahl Nitrogen (TKN) & $0.335-55.0$ \\
\hline
\end{tabular}

*Corresponding author: Udeme J. Ndon, Department of Civil and Environmental Engineering, San Jose State University, San Jose, CA 95192-0083, USA, Tel: 408-9243863; Fax: 408-924-4004; E-mail: udeme.ndon@sjsu.edu

Received October 25, 2017; Accepted November 27, 2017; Published December 02, 2017

Citation: Ndon UJ (2017) Trends in the Application of Permeable Pavement as Sustainable Highway Storm Water Management Option for Safe-Use of Roadways. J Civil Environ Eng 7: 288. doi: 10.4172/2165-784X.1000288

Copyright: ( $) 2017$ Ndon UJ. This is an open-access article distributed under the terms of the Creative Commons Attribution License, which permits unrestricted use, distribution, and reproduction in any medium, provided the original author and source are credited. 


\begin{tabular}{|c|c|}
\hline Total Phosphorous as $\mathrm{P}$ & $0.113-0.998$ \\
\hline Copper $(\mathrm{Cu})$ & $0.022-7.033$ \\
\hline Lead $(\mathrm{Pb})$ & $0.073-1.78$ \\
\hline Zinc $(\mathrm{Zn})$ & $0.056-0.929$ \\
\hline Fecal Coliform (organisms/100 ml) & $50-590$ \\
\hline
\end{tabular}

Table 2: Constituents and concentration in highway runoff [1].

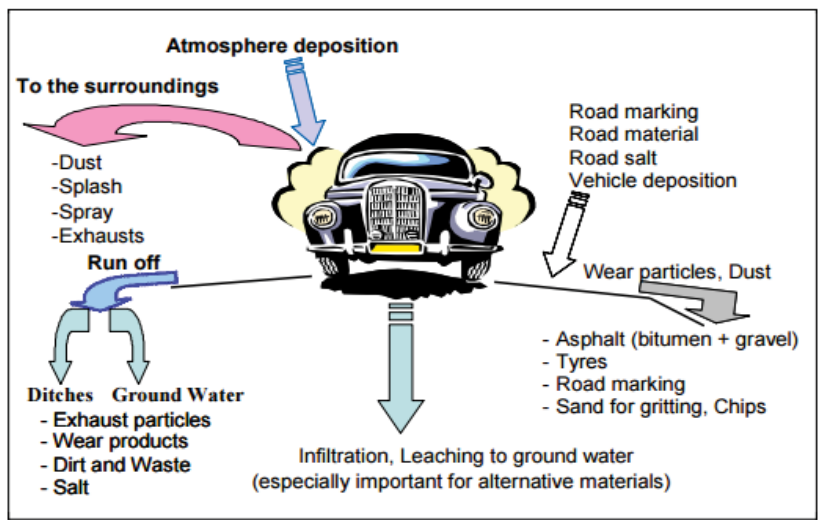

Figure 1: An illustration of various sources of contaminants in road environments [3].

\begin{tabular}{|c|c|c|}
\hline Topic & Transportation MS4 & City/County MS4 \\
\hline Location & $\begin{array}{c}\text { State transportation agencies } \\
\text { often own streets and highways } \\
\text { that can stretch for many miles, } \\
\text { and cross numerous waterways, } \\
\text { watersheds, and jurisdictions }\end{array}$ & $\begin{array}{r}\text { Local governments are typically } \\
\text { responsible for streets they own, } \\
\text { which are usually in a limited } \\
\text { geographical area }\end{array}$ \\
\hline $\begin{array}{c}\text { Population } \\
\text { served by } \\
\text { MS4 }\end{array}$ & $\begin{array}{r}\text { State transportation agencies } \\
\text { often serve a transient } \\
\text { population of drivers and } \\
\text { passengers }\end{array}$ & $\begin{array}{r}\text { Local governments often serve } \\
\text { residents and businesses in } \\
\text { their community boundaries }\end{array}$ \\
\hline Authorities & $\begin{array}{r}\text { State transportation agencies } \\
\text { have little to no enforcement } \\
\text { authority to implement } \\
\text { ordinances and must use other } \\
\text { mechanisms }\end{array}$ & $\begin{array}{r}\text { Local government can develop } \\
\text { and implement ordinances } \\
\text { that they then enforce in their } \\
\text { community boundaries }\end{array}$ \\
\hline
\end{tabular}

Table 3: Key differences between transportation MS4s and traditional (City/County) MS4s [3].

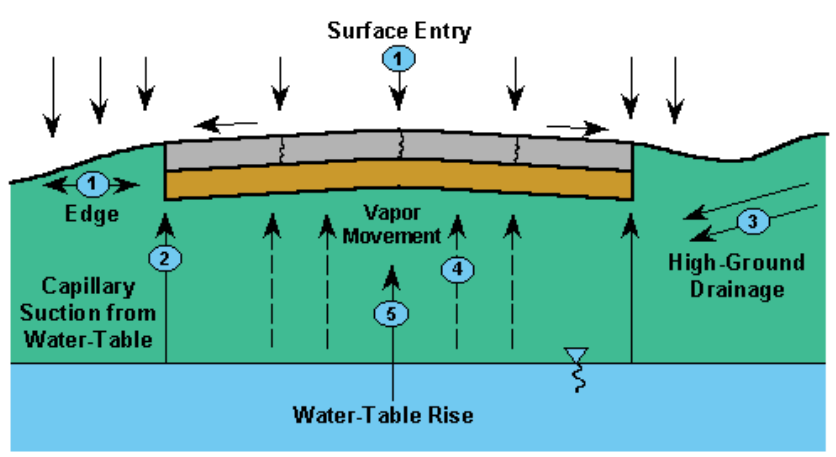

Figure 2: An illustration of surface and subsurface water impact on pavement [10].

separate sewer (MS4s) along streets, roads, and highways. Transportation agencies are responsible for the management of storm water runoff from highways. For some city roads and/or county roads, the responsibility may involve multiple agencies. Table 3 presents information on the key differences between storm sewer systems (MS4s) that are solely managed by transportation authorities and by city/county.
To comply with the U.S. EPA requirements, transportation agencies must install storm water best management practices (BMPs) to capture and treat storm water runoff from road surface. Road storm water runoff that is collected using engineered drainage system is typically treated to remove pollutants prior to discharge into streams or rivers and lakes or use to recharge groundwater by subsurface infiltration. Reports by U.S. Department of Transportation, Federal Highway Administration [1]; California Department of Transportation [4]; Pennsylvania Department of Environmental Protection [5]; Transportation Research Board [6]; Texas Transportation Institute [7]; California Department of Transportation [8] have detail information on BMPs for treating storm water runoff.

A different option for managing road storm water came into practice in the form of permeable pavement. Permeable pavement allows storm water to move through the pavement layers (away from the road surface) where it can drain into a piping system that delivers the collected water to a treatment process as needed. Some of the pollutants in the storm water have been noted to be removed as the storm water filters through the layers of the permeable pavement. By removing storm water from the road surface and by aiding the removal of pollutant from storm water, permeable pavement has been viewed as an environmental sustainable system. This has resulted in the advancement of the development of various types of permeable pavement, including the possibility of full-depth permeable pavement for certain sections of highways and urban roads. However, ability to manage the impact of water infiltration on strength and durability of permeable will continue to be the determining factor that controls the extent to which permeable pavement can be used to manage storm water, especially in highways where pavements are designed to carry heavy vehicles and fast speed conditions.

The primary objective of this article is to present a review of the literature on environmental pollution associated with highway storm water, storm water impact on durability of pavements and on road safety, storm water removal from road surfaces, types of permeable pavement used in sustainable management of highway storm water and the associated benefits.

\section{Impacts of Highway Storm water}

\section{Impact on durability of pavements}

Storm water falling on road surfaces as well as subsurface water must be drained away from pavement to prevent accumulation of water in the pavement structure that can result in pavement damage. Figure 2 presents an illustration of surface and subsurface water impact on pavement (Virginia Asphalt Association, undated) while Table 4 shows the various mechanisms through which water enters pavements (ingress) and exits pavement (egress).

Storm water intrusion including subsurface moisture into pavement structure is a major cause of pavement failures or damage. The literature contains extensive reports on moisture damage to pavement, including reports by Brown [9]; Fwa [10]; Kandhal et al. [11]; Julie and Rendong [12]; Pavement Interactive [13]; Pavement Interactive [14]; Pavement Interactive [15], Asphalt Institute [16], Yilmaz and Sargin [17], Pavement Interactive [18], California Department of Transportation (undated-1) [19], California Department of Transportation (undated-2) [20], California Department of Transportation [21], and Suryakanta [22].

Some specific common forms of distress in rigid cement or concrete pavement has been reported by Pavement Interactive [23], Suryakanta [22] and by California Department of Transportation [19]. The various 
types of concrete pavement defects where water is either the primary or contributing factor for the defect include: faulting, heave/swell, settlement, patch deterioration, scaling, popouts, corner cracking, intersecting cracking, pumping, joint seal damage, punchouts, D-cracking, ASR (AlkaliSilicate Reactivity), and freeze-thaw damage [19].

\begin{tabular}{|c|c|c|}
\hline \multirow{10}{*}{ Ingress } & \multirow{4}{*}{$\begin{array}{c}\text { Through the Pavement } \\
\text { Surface }\end{array}$} & Through construction joint \\
\hline & & Through cracks due to thermal or traffic loads \\
\hline & & Through cracks due to pavement failure \\
\hline & & Penetration through intact bound layers \\
\hline & \multirow{3}{*}{ From the Subgrade } & By artesian head in the subgrade \\
\hline & & By pumping action at formation level \\
\hline & & By capillary action in the subgrade \\
\hline & \multirow{3}{*}{$\begin{array}{l}\text { From the Road } \\
\text { Margins }\end{array}$} & By reverse falls at formation level \\
\hline & & By lateral/median drain surcharging \\
\hline & & By capillary action in the sub-base \\
\hline \multirow{6}{*}{ Egress } & \multirow{2}{*}{$\begin{array}{c}\text { Through the Pavement } \\
\text { Surface }\end{array}$} & Through cracks under pumping action \\
\hline & & Through the intact surfacing \\
\hline & \multirow{2}{*}{ Into the Subgrade } & By soak-away action \\
\hline & & By subgrade suction \\
\hline & \multirow{2}{*}{ To the Road Margins } & $\begin{array}{l}\text { Into lateral/median drains under gravitational } \\
\text { flow in the sub-base }\end{array}$ \\
\hline & & $\begin{array}{l}\text { Into positive drains through cross drains } \\
\text { action as collectors }\end{array}$ \\
\hline
\end{tabular}

Table 4: Mechanisms through which water enters (ingress) and exits (egress) pavements [11].

\begin{tabular}{|c|c|c|c|}
\hline $\begin{array}{c}\text { Road Weather } \\
\text { Variables }\end{array}$ & $\begin{array}{l}\text { Roadway } \\
\text { Impacts }\end{array}$ & $\begin{array}{l}\text { Traffic Flow } \\
\text { Impacts }\end{array}$ & Operational Impacts \\
\hline \multirow{2}{*}{$\begin{array}{l}\text { Air Temperature } \\
\text { and Humidity }\end{array}$} & \multirow{2}{*}{$\mathrm{N} / \mathrm{A}$} & \multirow{2}{*}{$\mathrm{N} / \mathrm{A}$} & $\begin{array}{l}\text { Road Treatment Strategy (e.g. } \\
\text { snow and ice control) }\end{array}$ \\
\hline & & & $\begin{array}{l}\text { Construction Planning (e.g. } \\
\text { paving and striping) }\end{array}$ \\
\hline \multirow{3}{*}{ Wind Speed } & $\begin{array}{l}\text { Visibility } \\
\text { Distance } \\
\text { (due to } \\
\text { blowing } \\
\text { snow, dust) }\end{array}$ & Traffic Speed & $\begin{array}{l}\text { Vehicle Performance (e.g. } \\
\text { stability) }\end{array}$ \\
\hline & $\begin{array}{c}\text { Lane } \\
\text { Obstruction } \\
\text { (due to wind- } \\
\text { blown snow, } \\
\text { debris) }\end{array}$ & $\begin{array}{c}\text { Travel Time } \\
\text { Delay }\end{array}$ & $\begin{array}{l}\text { Access Control (e.g. restrict } \\
\text { vehicle type, close road) }\end{array}$ \\
\hline & & Accident Risk & Evacuation Decision Support \\
\hline \multirow{7}{*}{$\begin{array}{l}\text { Precipitation } \\
\text { (type, rate, start/ } \\
\text { end times) }\end{array}$} & $\begin{array}{l}\text { Visibility } \\
\text { Distance }\end{array}$ & $\begin{array}{l}\text { Roadway } \\
\text { Capacity }\end{array}$ & $\begin{array}{l}\text { Vehicle Performance (e.g. } \\
\text { traction) }\end{array}$ \\
\hline & $\begin{array}{l}\text { Pavement } \\
\text { Friction }\end{array}$ & Traffic Speed & Driver Capabilities/Behavior \\
\hline & $\begin{array}{c}\text { Lane } \\
\text { Obstruction }\end{array}$ & $\begin{array}{l}\text { Traffic Time } \\
\text { Delay }\end{array}$ & Road Treatment Strategy \\
\hline & & Accident Risk & Traffic Signal Timing \\
\hline & & & Speed Limit Control \\
\hline & & & Evacuation Decision Support \\
\hline & & & Institutional Coordination \\
\hline \multirow{4}{*}{ Fog } & \multirow{4}{*}{$\begin{array}{l}\text { Visibility } \\
\text { Distance }\end{array}$} & Traffic Speed & Driver Capabilities/Behavior \\
\hline & & $\begin{array}{l}\text { Speed } \\
\text { Variance }\end{array}$ & Road Treatment Strategy \\
\hline & & $\begin{array}{l}\text { Travel Time } \\
\text { Delay }\end{array}$ & Access Control \\
\hline & & Accident Risk & Speed Limit Control \\
\hline $\begin{array}{l}\text { Pavement } \\
\text { Temperature }\end{array}$ & $\begin{array}{l}\text { Infrastructure } \\
\text { Damage }\end{array}$ & N/A & $\mathrm{R}^{`} \mathrm{OAD}$ Treatment Strategy \\
\hline $\begin{array}{l}\text { Road Weather } \\
\text { Variables }\end{array}$ & $\begin{array}{l}\text { Roadway } \\
\text { Impacts }\end{array}$ & $\begin{array}{l}\text { Traffic Flow } \\
\text { Impacts }\end{array}$ & Operational Impacts \\
\hline
\end{tabular}

\begin{tabular}{|c|c|c|c|}
\hline \multirow{5}{*}{$\begin{array}{l}\text { Pavement } \\
\text { Condition }\end{array}$} & $\begin{array}{l}\text { Pavement } \\
\text { Friction }\end{array}$ & $\begin{array}{l}\text { Roadway } \\
\text { Capacity }\end{array}$ & Vehicle Performance \\
\hline & $\begin{array}{c}\text { Infrastructure } \\
\text { Damage }\end{array}$ & Traffic Speed & $\begin{array}{l}\text { Driver Capabilities/Behavior } \\
\text { (e.g. route choice) }\end{array}$ \\
\hline & & $\begin{array}{l}\text { Travel Time } \\
\text { Delay }\end{array}$ & Road Treatment Strategy \\
\hline & & Accident Risk & Traffic Signal Timing \\
\hline & & & Speed Limit Control \\
\hline \multirow{3}{*}{ Water Level } & \multirow{3}{*}{$\begin{array}{l}\text { Lane } \\
\text { Submersion }\end{array}$} & Traffic Speed & Access Control \\
\hline & & $\begin{array}{l}\text { Travel Time } \\
\text { Delay }\end{array}$ & Evacuation Decision Support \\
\hline & & Accident Risk & Institutional Coordination \\
\hline
\end{tabular}

Table 5: Weather impacts on roads including traffic and operational decisions [30].

Pavement Interactive [24] and the California Department of Transportation [21] have presented summaries of some forms of distress in flexible (asphalt) pavements. The various types of asphalt cement pavement defects where water (or moisture) is the responsible or contributing factor for the defects are: edge cracking, overlay bumps, stripping, potholes, and pumping. In addition, depression of asphalt pavements is reported by Pavement Interactive [24] as a defect that is caused by freezing of internal moisture in the pavement. Also, Neal [25] reports that upheaval (swelling) of asphalt pavement is a defect that is caused by expansion of the subgrade soil due to moisture or frost heave.

Pictures of some of the pavement defects caused by water or moisture infiltration are presented in the report by Ndon and Al-Manaseer [26]. As will be presented later, the negative impact of water on pavement durability along with the impact associated with voids (that are needed for water infiltration) on strength are some of the challenges that has to be addressed to enable the use of full-depth permeable pavement for fast and heavy traffic.

\section{Impacts on road safety}

This section presents information on road safety issues associated with the accumulation of storm water on pavement surfaces. The U.S. Department of Transportation, Federal Highway Administration [27], reports that weather conditions which include storm events (precipitation) and water accumulation on pavement are factors that impact road safety. The information presented in Table 5 presents impacts of poorly managed roadway storm water on road safety including impact on visibility distance on the roadway, pavement friction, lane obstruction, infrastructure damage (such as pavement damage, and lane submersion).

Specifically, accumulation of storm water on road surfaces creates conditions that reduces safety of the traveling public due to: (1) splash and spray of road water, (2) reduced skid resistance (reduced pavement friction coefficient), and (3) hydroplaning problem.

Splash and spray of road water: Accumulation of storm water on road surfaces creates conditions that reduce safety of the traveling public due to splash and spray of road water. As shown in Figure 3, splash and spray of road water can significantly reduce visibility on the roadway and can result in car crashes.

Friction coefficient (Skid resistance) of wet road surfaces: The presence of storm water on road surfaces reduces pavement friction which often results in skidding while driving on a wet road surface. Skidding can result in total loss of control of a vehicle which may lead to an accident. According to Wilson [28], four factors affect skid properties of a road. The four factors are pavement surface aggregate 
factors, load factors, environmental factors and vehicle factors. These factors are presented in Table 6 .

Various studies have shown that the friction coefficient (a measure of skid resistance) of road surfaces decreases with wet pavement surfaces [29]. The impact of a rain event on the friction coefficient of road surfaces is presented in Figure 4, which shows decreasing road friction coefficient during rain events. Figure 5 presents an example of road signs used by transportation agencies to warn the public about potential skidding and/or, sliding.

Hydroplaning due to accumulated storm water on road surfaces: Hydroplaning is a phenomenon where vehicle tires lose contact with

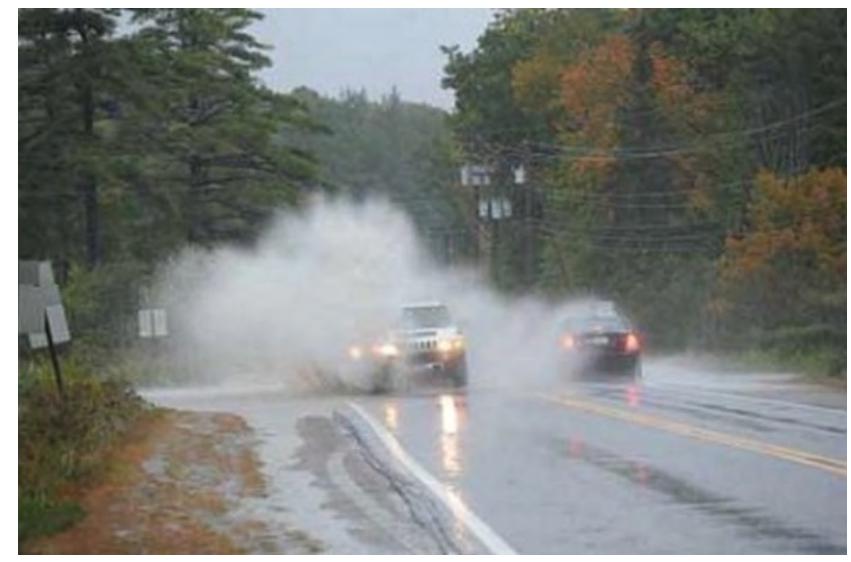

Figure 3: Plash and `spray of road water [31].

\begin{tabular}{|c|c|c|c|}
\hline $\begin{array}{l}\text { Pavement surface } \\
\text { aggregate factors }\end{array}$ & Load factors & $\begin{array}{c}\text { Environmental } \\
\text { factors }\end{array}$ & Vehicle factors \\
\hline $\begin{array}{l}\text { Geological properties of } \\
\text { the surfacing aggregate }\end{array}$ & $\begin{array}{l}\text { Age of the } \\
\text { surface }\end{array}$ & $\begin{array}{l}\text { Water film } \\
\text { thickness } \\
\text { and drainage } \\
\text { conditions }\end{array}$ & Vehicle speed \\
\hline $\begin{array}{l}\text { Surface texture } \\
\text { (microtexture and } \\
\text { macrotexture) }\end{array}$ & $\begin{array}{c}\text { Traffic } \\
\text { intensity and } \\
\text { composition } \\
\text { - equivalent } \\
\text { vehicle loading }\end{array}$ & $\begin{array}{c}\text { Surface } \\
\text { contamination }\end{array}$ & $\begin{array}{c}\text { Angle of the tyre to } \\
\text { the direction of the } \\
\text { moving vehicle }\end{array}$ \\
\hline Chip size and shape & Road geometry & Temperature & The wheel-slip ratio \\
\hline \multirow{2}{*}{$\begin{array}{c}\text { Types of surfacing } \\
\text { (concrete, asphalt mix } \\
\text { and mix design, chipseal } \\
\text { surface and design } \\
\text { method) }\end{array}$} & \multirow{2}{*}{$\begin{array}{l}\text { Traffic flow } \\
\text { conditions - } \\
\text { congestion or } \\
\text { free-flowing }\end{array}$} & & $\begin{array}{l}\text { Tyre characteristics } \\
\text { (structural type, } \\
\text { hardness and wear) }\end{array}$ \\
\hline & & Rainfall & $\begin{array}{l}\text { Tyre tread depth } \\
\text { and pattern }\end{array}$ \\
\hline
\end{tabular}

Table 6: Factors affecting the skid properties of a road [32].

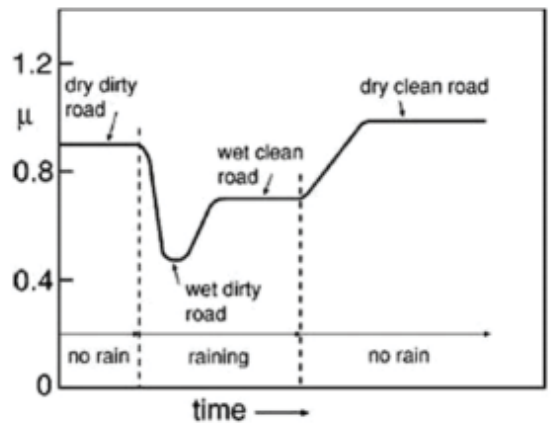

Figure 4: Relationship between friction coefficient of road surface and time of storm event [33].

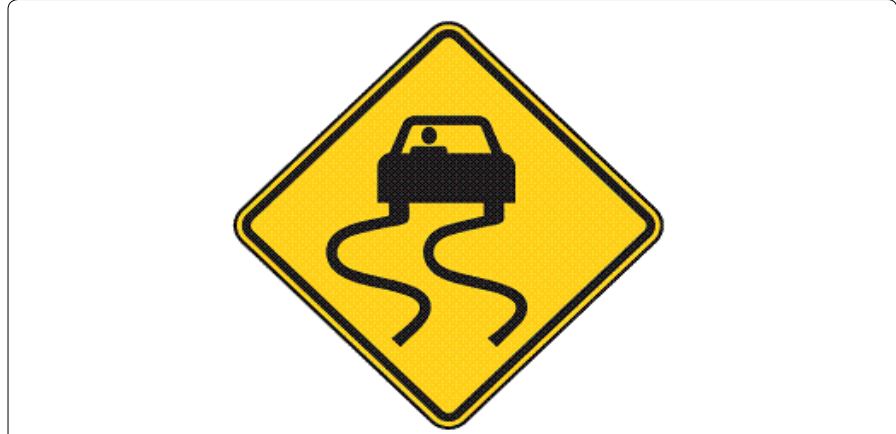

Figure 5: An example of road signs about potential skidding, sliding or hydroplaning hazard [34].

\begin{tabular}{|c|c|c|c|}
\hline \multicolumn{2}{|c|}{ Water Depth } & \multicolumn{2}{|c|}{ Sensitivity to Water Depth } \\
\hline Roadway Factors & $\begin{array}{l}\text { Environmental } \\
\text { Factors }\end{array}$ & Driver Factors & Vehicle Factors \\
\hline Compacted wheel ruts & \multirow{8}{*}{$\begin{array}{c}\text { Rainfall } \\
\text { intensity } \\
\text { Rainfall duration }\end{array}$} & Speed & Tire tread wear \\
\hline Pavement micro-texture & & Acceleration & Tire pressure \\
\hline Pavement macro-texture & & Braking & Vehicle type \\
\hline Pavement cross-slope & & Steering & \\
\hline Roadway grade & & & \\
\hline Width of pavement & & & \\
\hline Roadway curvature & & & \\
\hline Longitudinal depressions & & & \\
\hline
\end{tabular}

Table 7: Factors that affect hydroplaning [35].

\begin{tabular}{|c|c|}
\hline Speed $(\mathbf{m p h})$ & Critical Water Depth (inches) \\
\hline Greater than 50 & 0.05 \\
\hline $45-50$ & 0.1 \\
\hline Less than 45 & 0.2 \\
\hline
\end{tabular}

Table 8: Suggested hydroplaning critical water depth for various vehicle speed [35].

the pavement surface due to accumulated storm water on the road pavement. Glennon [30] reported that water depth on pavement surfaces and sensitivity to water depth are the two major parameters that control hydroplaning on wet pavement surfaces as summarized in Table 7. Table 8 presents suggested critical water depth on road pavements for various vehicle speeds. Table 8 also shows low critical water depth at higher vehicle speeds which is why it is advisable to drive at low speed under wet pavement condition, especially when there is water on the road surface.

Hydroplaning can also result from the accumulation of storm water on road surface due to rutting. Rutting of pavement is the presence of depression in the wheel-tracks of roadways. Pavement rutting occurs more frequently on the surface of flexible (asphalt) pavement. When rutting of pavement occurs, it allows the accumulation of storm water on wheel-tracks of roadways that increase hydroplaning on roads. Roadways with depression in the wheel-tracks and associated accumulation of water in the wheel-tracks of rutted pavement are illustrated in Figure 6.

Critical wheel rut depth associated with pavement cross-slope for selected critical water depth at various vehicle speeds reported by Glennon [30] is presented in Table 9. The data in Table 9 shows lower critical wheel rut depth for high speed conditions as compared to low speed conditions. 
Wet pavement accident statistics: Average weather-related crash statistics for ten-year period (2005-2014) have been reported by the U.S. Department of Transportation, Federal Highway Administration [27]. These statistics are presented in Table 10. The statistics show that there were about 1,258,978 weather-related crashes each year between 2005 and 2014 where weather-related crashes are defined as those

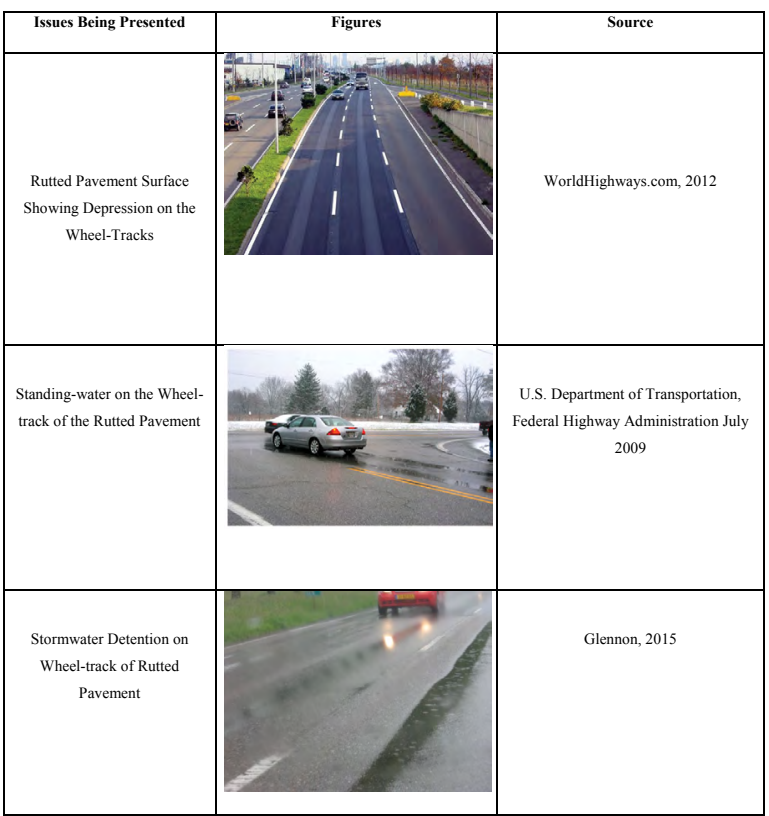

Figures 6: Rutted pavement and storm water detention on the depressed surface.

\begin{tabular}{|c|c|c|c|}
\hline Speed (mph) & $\begin{array}{l}\text { Critical water } \\
\text { Depth (inches) }\end{array}$ & $\begin{array}{l}\text { Pavement Cross } \\
\text { Slope (in/in) }\end{array}$ & $\begin{array}{c}\text { Critical Wheel Rut Depth } \\
\text { (inches) }\end{array}$ \\
\hline \multirow{5}{*}{ Greater than 50} & \multirow{5}{*}{0.05} & 0.005 & 0.14 \\
\hline & & 0.01 & 0.23 \\
\hline & & 0.015 & 0.32 \\
\hline & & 0.02 & 0.41 \\
\hline & & 0.025 & 0.5 \\
\hline \multirow{5}{*}{$45-50$} & \multirow{5}{*}{0.1} & 0.005 & 0.19 \\
\hline & & 0.01 & 0.28 \\
\hline & & 0.015 & 0.37 \\
\hline & & 0.02 & 0.46 \\
\hline & & 0.025 & 0.55 \\
\hline \multirow{5}{*}{ Less than 45} & \multirow{5}{*}{0.2} & 0.005 & 0.29 \\
\hline & & 0.01 & 0.38 \\
\hline & & 0.015 & 0.47 \\
\hline & & 0.02 & 0.56 \\
\hline & & 0.025 & 0.65 \\
\hline
\end{tabular}

Table 9: Critical wheel rut depth with associated critical water depth and pavement cross slopes for various vehicle speeds [35].

\begin{tabular}{|c|c|c|}
\hline \multirow{5}{*}{$\begin{array}{l}\text { Weather-Related }{ }^{*} \text { Crashes, } \\
\text { Injuries, and Fatalities }\end{array}$} & \multicolumn{2}{|c|}{ Weather-Related Crash Statistics } \\
\hline & $\begin{array}{c}\text { 10-Year Average } \\
(2005-2014)\end{array}$ & 10-Year Percent \\
\hline & $1,258,978$ crashes & $\begin{array}{l}22 \% \text { of vehicle } \\
\text { crashes }\end{array}$ \\
\hline & $\begin{array}{l}445,303 \text { persons } \\
\text { injured }\end{array}$ & $19 \%$ of crash injuries \\
\hline & 5,897 persons killed & $16 \%$ of crash fatalities \\
\hline
\end{tabular}

*"Weather-Related" crashes are those that occur in the presence of adverse weather and/or slick pavement conditions.

Table 10: Weather impacts on road safety: Weather-related annual average crash statistics [30].

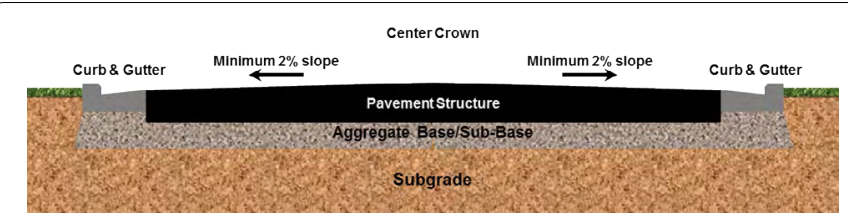

Figure 7: Cross-section of a two-lane road with curb and gutter for draining of road runoff [10].

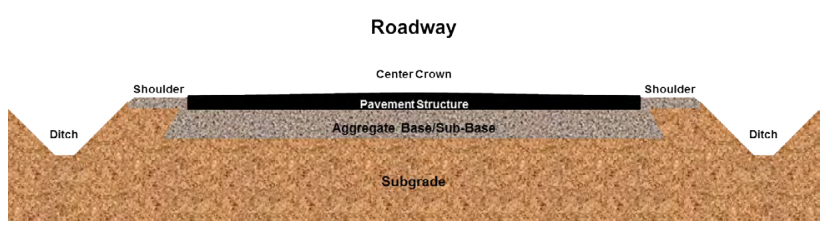

Figure 8: Cross-section of a two-lane road with ditches for draining of road runoff [10].

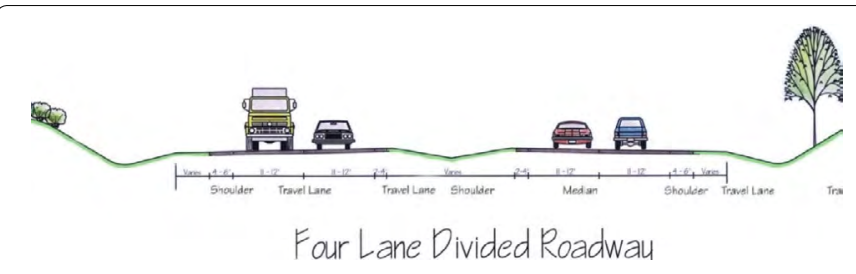

Figure 9: Cross-section of a four-lane divided roadway for draining of road runoff [38].

crashes that occur in adverse weather (i.e., rain, sleet, snow, fog, severe crosswinds, or blowing snow/sand/debris) or on slick pavement (i.e., wet pavement, snowy/slushy pavement, or icy pavement). Table 10 also shows that about 5,897 people were killed while 445,303 people were injured in highway weather related accidents each year between 2005 and 2014. According to the report [27], the vast majority of most weather-related crashes happen on wet pavement and during rainfall.

Accumulation of storm water on road surfaces results in various forms of pavement damage reduces skid resistance (friction coefficient) of pavements, causes hydroplaning, results in plash and spray of road water all of which lead to car crashes, injuries and fatalities. Therefore, draining of storm water from pavement surfaces is critical for pavement durability as well as provision of dry pavement surfaces with associated skid resistance for the safety of the traveling public.

\section{Storm water Removal from Impervious Pavement Surfaces}

Storm water removal from impervious road surfaces has been an integral component of highway design that is commonly achieved by extensive drainage systems that combine curbs, storm sewer and ditches. The road surfaces are engineered to slope to the sides with a crown at the center. The sloping surfaces allow storm water to move away from the road surfaces to where the water is collected using gutter at the curb or ditches.

According to Virginia Department of Transportation [31], curb and gutters are used in urban streets. Figure 7 presents an illustration of an urban street that uses curb and gutter. Alternatively, ditches are used to collect storm water from city streets [32] as illustrated in Figure 8. In the case of divided roadways as highways, the rainwater is also collected at the median that divides the roadway as illustrated in Figure 9. Storm water collected from the road drainage system is treated prior to discharge into the environment. 


\section{Permeable Pavement}

The primary difference between conventional pavement and permeable pavement is the presence of pores (voids or openings) in permeable pavement, including the pavement surface, which reduces imperviousness and allows infiltration of water such as storm water into and through the pavement. The infiltration of storm water through permeable pavement provides sustainable management strategy for storm water which eliminates or reduces environmental and safety problems associated with accumulation of storm water on impervious pavement surfaces. The American Association of State Highway and Transportation Officials (AASHTO) have presented a typical schematic of permeable pavement infiltration types as shown in Figure 10 [33]. Storm water that filters into permeable pavements is collected underneath the permeable layers (above the subgrade layer of pavements) and piped out for treatment and shown in "part c" of Figure 1 below. The illustrations in parts "a" and "b" of Figure 10 are not recommended if soil and ground water pollution can result from the storm water infiltration.
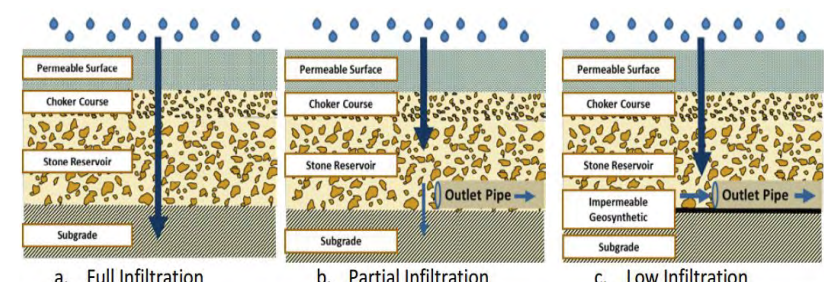

a. Full Infiltration

b. Partial Infiltration

c. Low Infiltration

Figure 10: Permeable pavement infiltration types [39].

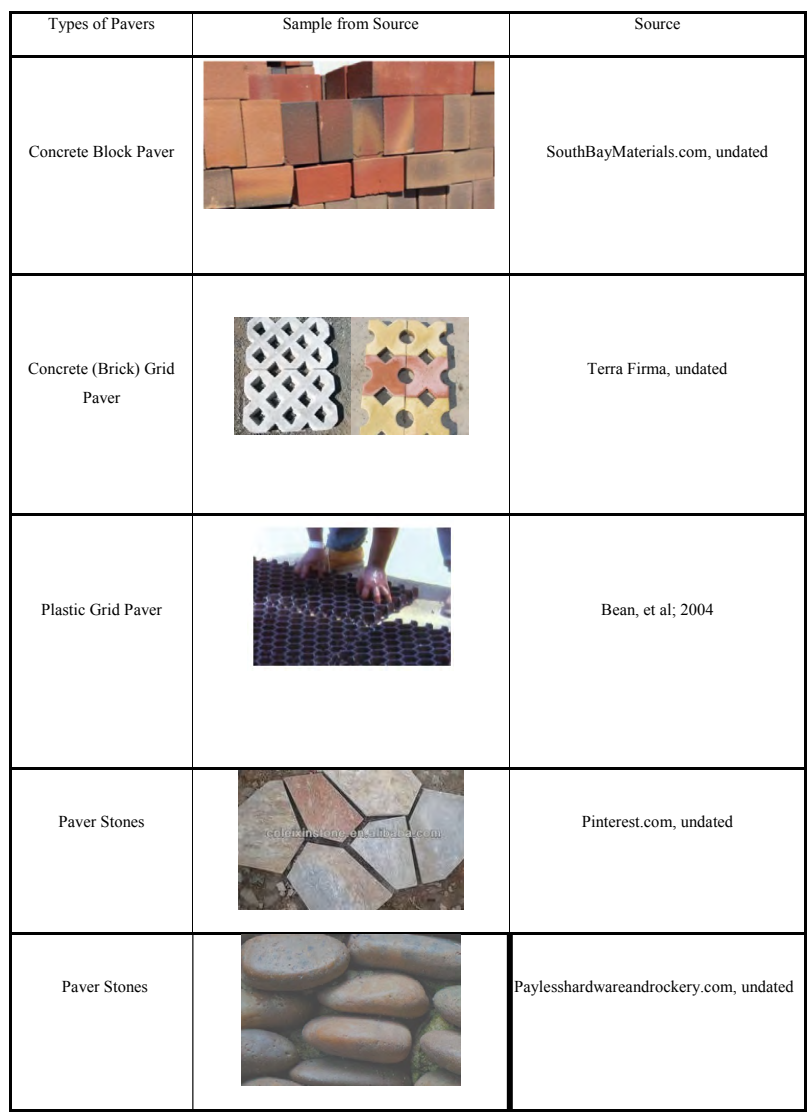

Figure 11: Examples of various types of pavers

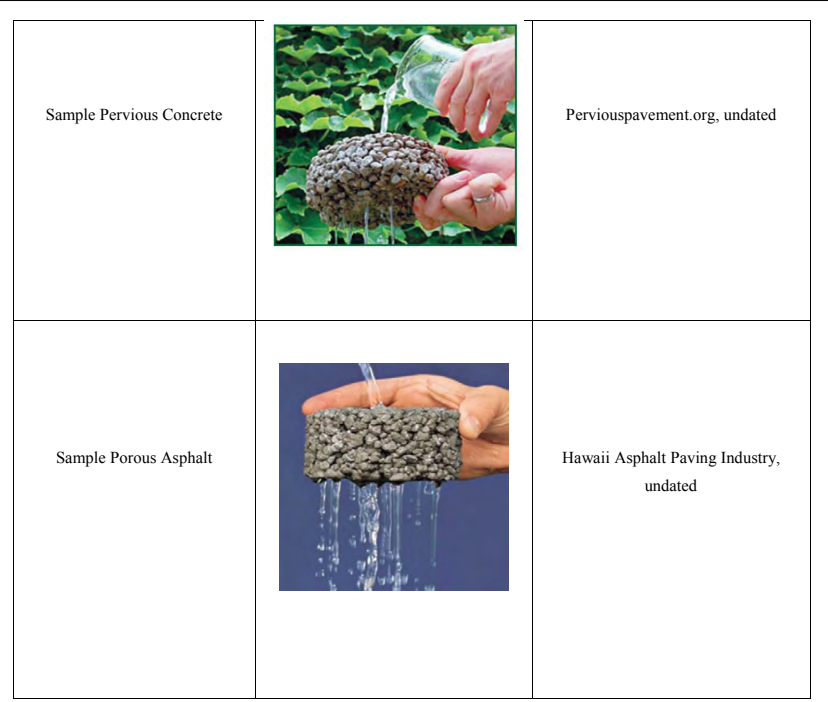

Figure 12: Water draining through a specimen of pervious concrete and porous asphalt.

Significant progress has been made in the application of permeable pavement over the past two decades [34]. This has resulted in three main groups of permeable pavement based on the type of paving material that make-up the surface of pavement, namely; pavers, concrete, and asphalt.

Pavers include Interlocking concrete pavers, brick pavers, stone pavers, grid concrete pavers, and grid plastic pavers [35-38]. Grid pavers include concrete grid pavers (CGP) and plastic grid pavers (PGP) with openings that can be filled with gravel or grass/turf. Pictures of some pavers are presented in Figure 11.

Permeable pavement having concrete as surface material is frequently referred to as "pervious concrete" while permeable pavement that has asphalt surface is frequently referred as "porous asphalt". Pervious concrete and porous asphalt are derived from mix designs that have less fine materials. With less fine materials, voids are created due to the reduced binding between the cementing material and course aggregates. Figure 12 presents picture of water filtering through pervious concrete specimen and porous asphalt specimen.

There is no consistency in the literature on the use of the words "permeable" "pervious", and "porous". These three words are commonly used interchangeably to have the same meaning; that which allows passage of water due to the presence of voids. With the three main groups of permeable paving materials, there is no uniformity in the use of the phrases "permeable pavement", "porous pavement", and "pervious pavement" that clearly define the type of pavement as well as the functional use of the pavement. Some literature tend to use the phrase "porous pavement" to refer to permeable asphalt pavement and the phrase "pervious pavement" to refer to permeable concrete pavement. Also, it is common to find "pavers" being referred to as permeable pavement without information on the material that is used for the pavement surface. This information becomes essential in identifying the strength and the associated functional use of the pavement. The author of this manuscript recommends adding the name of the paving material (asphalt, concrete, pavers) to the word "permeable", porous, or pervious to eliminate or reduce the confusion associated with current naming of permeable pavement.

Figures 13 and 14 present sample cross-sectional views of structural component of pavers while Figures 15 and 16 present sample crosssectional views of structural components of pervious concrete and 
porous asphalt pavements. The need for water infiltration in permeable pavements requires voids that result from the use of little or no binder fine materials. According to ConcreteNetwork.com [39,40], pervious concrete pavement has a large volume of interconnected voids of about 12 to 35 percent. The required void ratio for permeable pavement is controlled by hydrological as well as structural design factors. Since void ratio controls permeability and strength of the pavement, low void ratio would result in low permeability but higher strength of pavement.

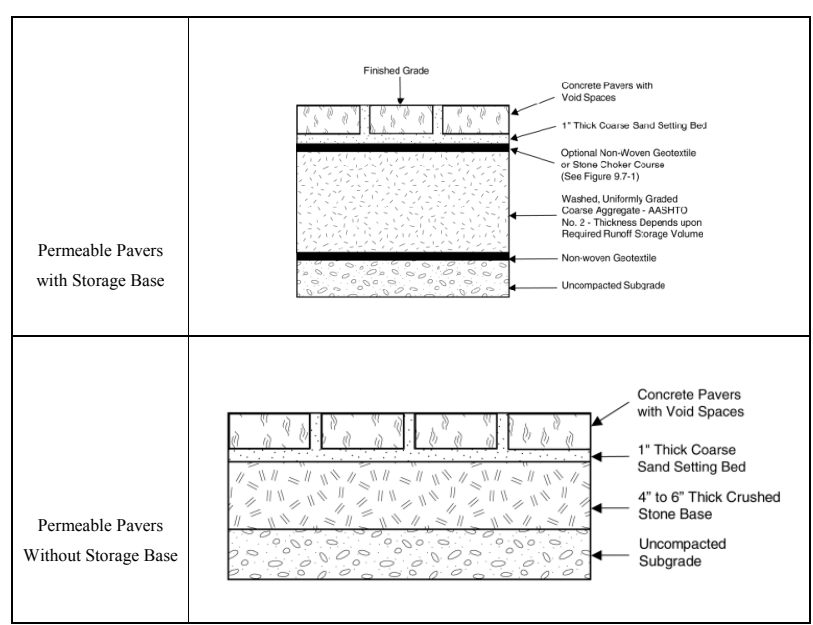

Figure 13: Typical details of pavers with and without storage base (National Association of City Transportation Officials, February 2004)

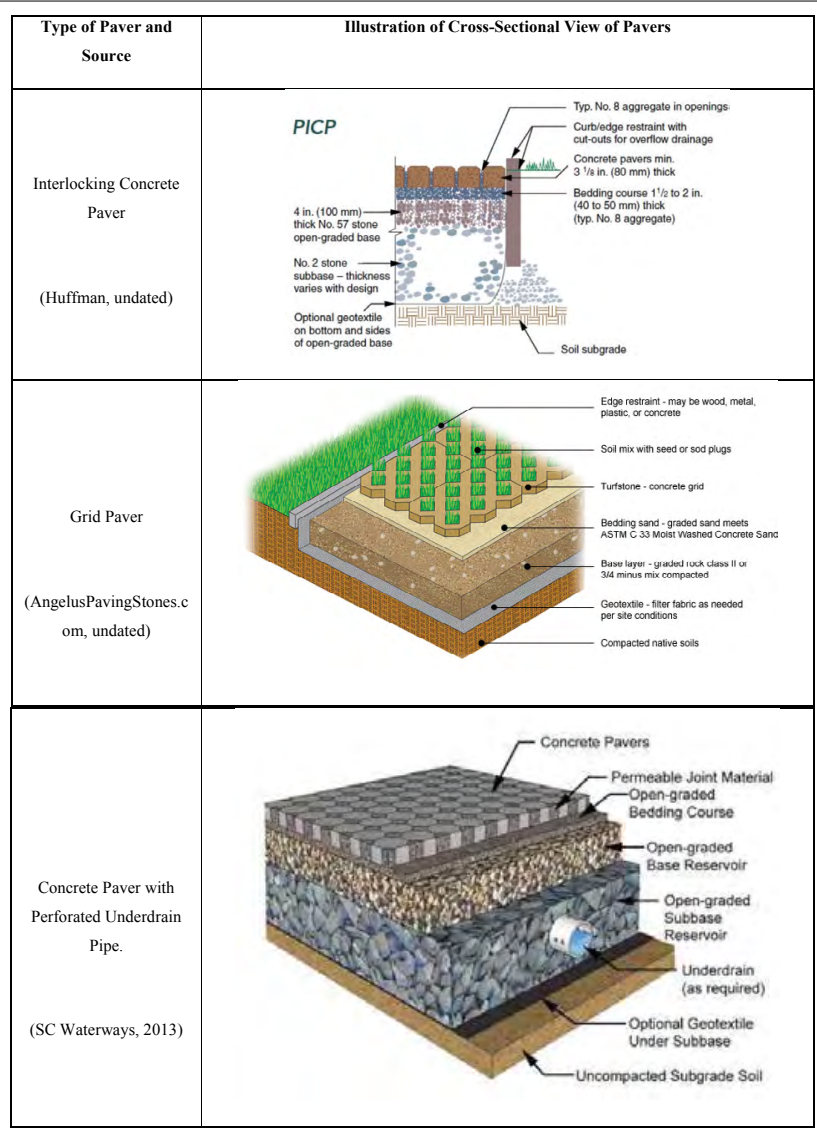

Figure 14: Illustrations of cross-sectional view of structural components of pavers.

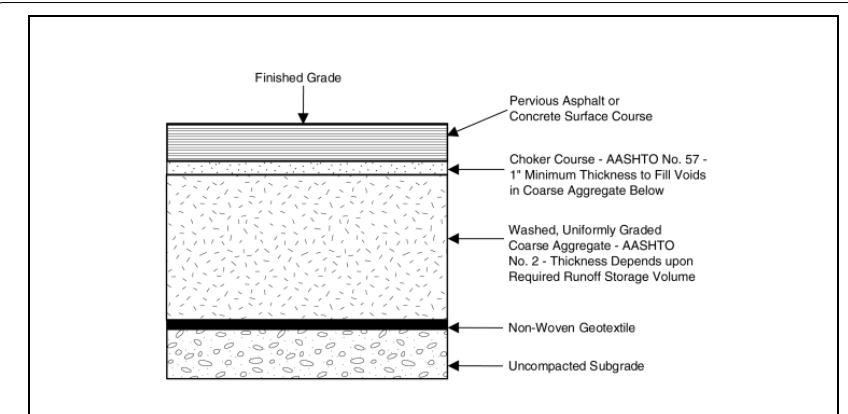

Figure 15: Typical details of pervious concrete or porous asphalt pavement with storage base.

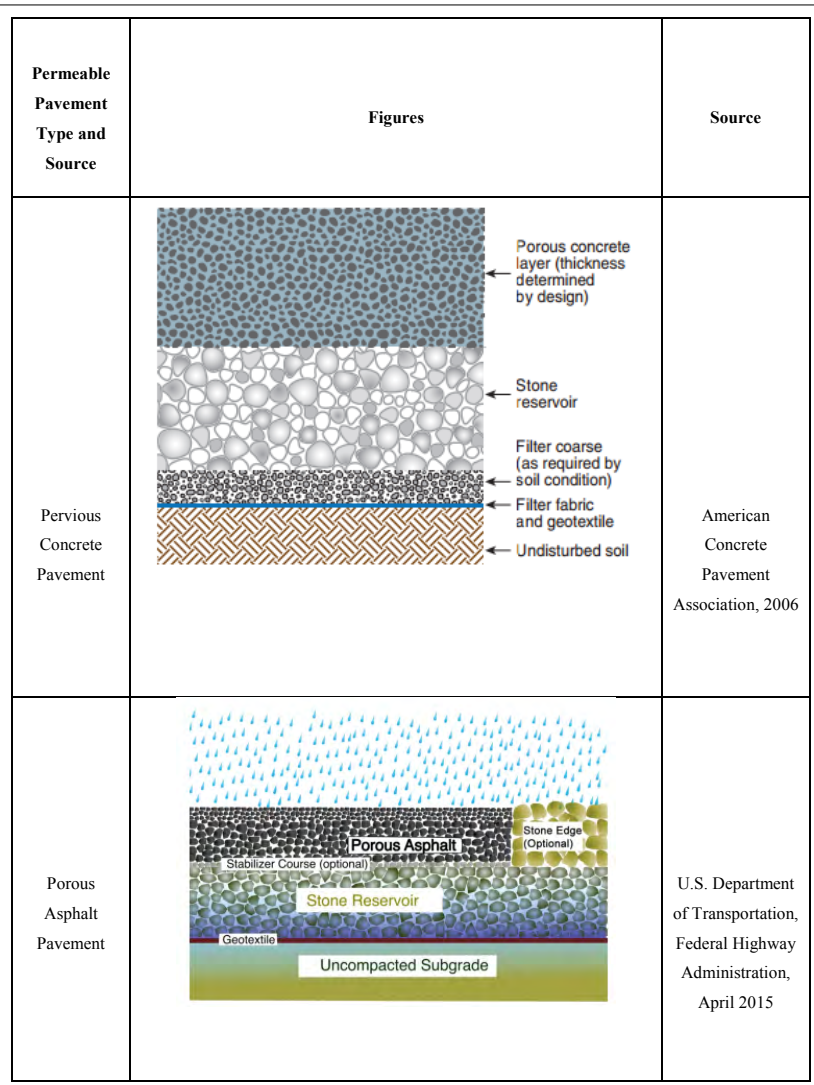

Figure 16: Illustrations of cross-sectional view of structural components of pervious concrete pavement and porous asphalt pavement.

In addition to presence of voids for water infiltration, as presented in Figures 13-16, some permeable pavements require little or no compaction of soil (subgrade) while some requires water storage (reservoir) layer that is achieved with the use of loosely packed stones as illustrated in Figure 17. The presence of voids, un-compacted subgrade, and reservoir layer are all associated with a concern about the strength of permeable pavements. According to the Minnesota Department of Natural Resources [41], permeable pavement are used for areas with light-traffic at commercial and residential sites to replace traditional impervious surfaces of low-speed roads, alleys, parking lots, driveways, sidewalks, plazas and patios.

However, design progress has resulted in the application of permeable pavement being extended beyond its initial application for foot and bicycle traffic to low speed vehicular traffic. The Virginia Department of Environmental Quality [42] presents three design scales 
for permeable pavement that include large-scale application, including application for foot traffic, light vehicles and heavy vehicles (Table 11). The California Department of Transportation [43] presents a table of categories of permeable pavements with examples of functions for each category (Table 12) where the use of permeable pavement for high speed traffic is associated with high risk. Specific examples of application of permeable pavement from the literature are summarized below.

\section{Permeable pavement for foot and bicycle traffic}

Permeable pavements have been used for decades for foot and bicycle traffic which include walkways, sidewalks, alleys, courtyards, and pedestrian plazas where foot and bicycles can be considered as the dominant traffic. Figures 18 and 19 present these applications where pavers, pervious concrete and porous asphalt have all been used for this class of application.

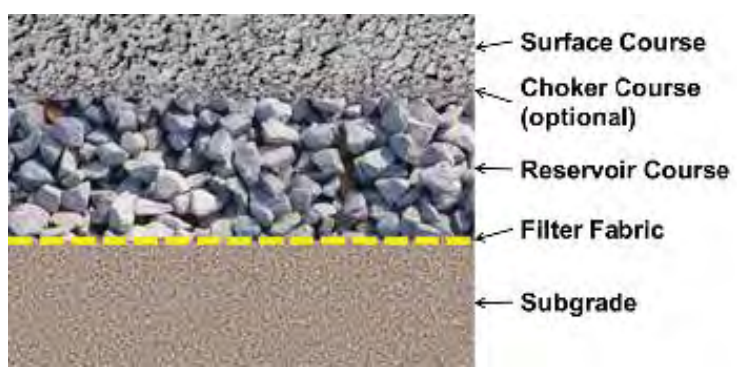

Figure 17: Picture showing loose stone reservoir layer in a permeable pavement.

\section{Permeable pavement for light, slow speed vehicular traffic}

Advancement of the design of permeable pavement have resulted in the use of pavers, permeable concrete and permeable asphalt for low speed and light-traffic areas such driveways, parking lots and residential streets. Figures 19 and 20 present examples of various permeable driveways and parking lots used for light, slow speed vehicular traffic. Figure 21 presents examples of paver residential streets while Figure 22 presents examples of pervious concrete and porous asphalt residential streets.

\section{Permeable pavement for heavy, slow speed vehicular traffic}

Application of permeable pavement (full-depth permeable pavement) for heavy vehicles is currently restricted to parking lots. The literature reports on various installations of pervious concrete parking lot for heavy vehicles where the vehicle speed is slow. Various pervious concrete parking lots for heavy vehicles are presented in Figure 23.

\section{Permeable pavement for high-speed, light and heavy vehicle} traffic (Permeable friction course)

While full-depth permeable pavements for highways (high-volume, high-speed roads) are yet to be developed, the removal of highway storm water by infiltration is presently achieved using permeable (or porous) friction course (PFC) also called open-graded friction courses (OGFC). According to National Asphalt Pavement Association [44], OGFC is an open-graded Hot-Mix Asphalt (HMA) mixture with interconnecting voids that provides improved surface drainage during rainfall where the rainwater drains vertically through the OGFC to impermeable underlying layer at where that water moves latterly to the edge of the OGFC.

\begin{tabular}{|c|c|c|c|}
\hline Design Factors & Micro-Scale Pavement & Small-Scale Pavement & Large-Scale Pavement \\
\hline Impervious Area Treated & 250 to 1000 sq. ft. & 1000 to 10,000 sq. ft. & More than 10,000 sq. ft. \\
\hline \multirow{5}{*}{ Typical Applications } & Driveways & Sidewalk Network & Parking Lots with more than 40 spaces \\
\hline & Walkways & Fire Lanes & Low Speed Residential Streets \\
\hline & Court Yards & Road Shoulders & \\
\hline & Plazas & Spill-Over Parking & \\
\hline & Individual Sidewalks & Plazas & \\
\hline Most Suitable Pavement & IP & $\mathrm{PA}, \mathrm{PC}$, and IP & $\mathrm{PA}, \mathrm{PC}$, and IP \\
\hline \multirow{2}{*}{ Load Bearing Capacity } & Foot traffic & \multirow{2}{*}{ Light vehicles } & \multirow{2}{*}{ Heavy vehicles (moving and parked) } \\
\hline & Light vehicles & & \\
\hline Reservoir Size & $\begin{array}{l}\text { Infiltration or detain some or } \\
\text { all of the TV }\end{array}$ & \multicolumn{2}{|c|}{ Infiltrate or detain the full Tv and as much of the CPv and design storms as possible } \\
\hline External Drainage Area? & No & \multicolumn{2}{|c|}{$\begin{array}{l}\text { Yes, impervious cover up to twice the permeable pavement area may be accepted as } \\
\text { long as sediment source controls and/or pretreatment is used }\end{array}$} \\
\hline Observation Well & No & No & Yes \\
\hline Underdrain? & Rare & Depends on the soil & Back-up underdrain \\
\hline Required Soil Tests & One per practice & Two per practice & One per 5000 sq. ft of proposed practice \\
\hline \multirow{2}{*}{ Building Setbacks } & 5 feet down-gradient & 10 feet down-gradient & 25 feet down-gradient \\
\hline & 25 feet up-gradient & 50 feet up-gradient & 100 feet up-gradient \\
\hline
\end{tabular}

Table 11: The three design scales for permeable pavement [48].

\begin{tabular}{|c|c|c|c|c|}
\hline Category & Examples & Loading & Speed & Risk \\
\hline A & $\begin{array}{l}\text { Landscape area, sidewalks and bike paths (with no vehicular access), } \\
\text { miscellaneous pavement to accept runoff from adjacent impervious areas } \\
\text { (e.g. roofs) }\end{array}$ & No vehicular loads & $\mathrm{N} / \mathrm{A}$ & Low \\
\hline B & $\begin{array}{c}\text { Parking lots, park \& ride areas, maintenance access roads, scenic } \\
\text { overview areas, sidewalks and bike paths (with maintenance/vehicular } \\
\text { access), maintenance vehicle pullout }\end{array}$ & Few heavy loads & Low-speed (less than $30 \mathrm{mph}$ ) & Low \\
\hline $\mathrm{C}$ & Rest areas, maintenance stations & $\begin{array}{l}\text { Moderate heavy } \\
\text { loads }\end{array}$ & Low-speed & Low \\
\hline $\mathrm{D}$ & $\begin{array}{l}\text { Shoulders, some low volume roads, areas in front of noise barriers } \\
\text { (beyond the traveled way) }\end{array}$ & $\begin{array}{l}\text { Moderate heavy } \\
\text { loads }\end{array}$ & High-speed & High \\
\hline$E$ & Highways, weigh stations & High heavy loads & High-speed & High \\
\hline
\end{tabular}

Table 12: Pervious pavement categories [49]. 
The voids (air voids) in OGFC are created due to the use of small amount of fine aggregate [45]. Explaining further, Ephenryecocenter. com [46] reports that OGFC is usually composed of 15 - to 25 millimeterthick hot-mix asphalt (open-graded) (HMA-O) constructed as surface overlay over an existing (or new) impervious asphalt pavement which allows surface water to penetrate vertically within the OGFC and then laterally moves towards the shoulder and still needs to be collected or treated. Typical design parameters including hydraulic conductivity (or infiltration flow rate), void content, thickness of the friction course layer and maximum aggregate size used in different European countries and some U.S. state are presented in Table 13.

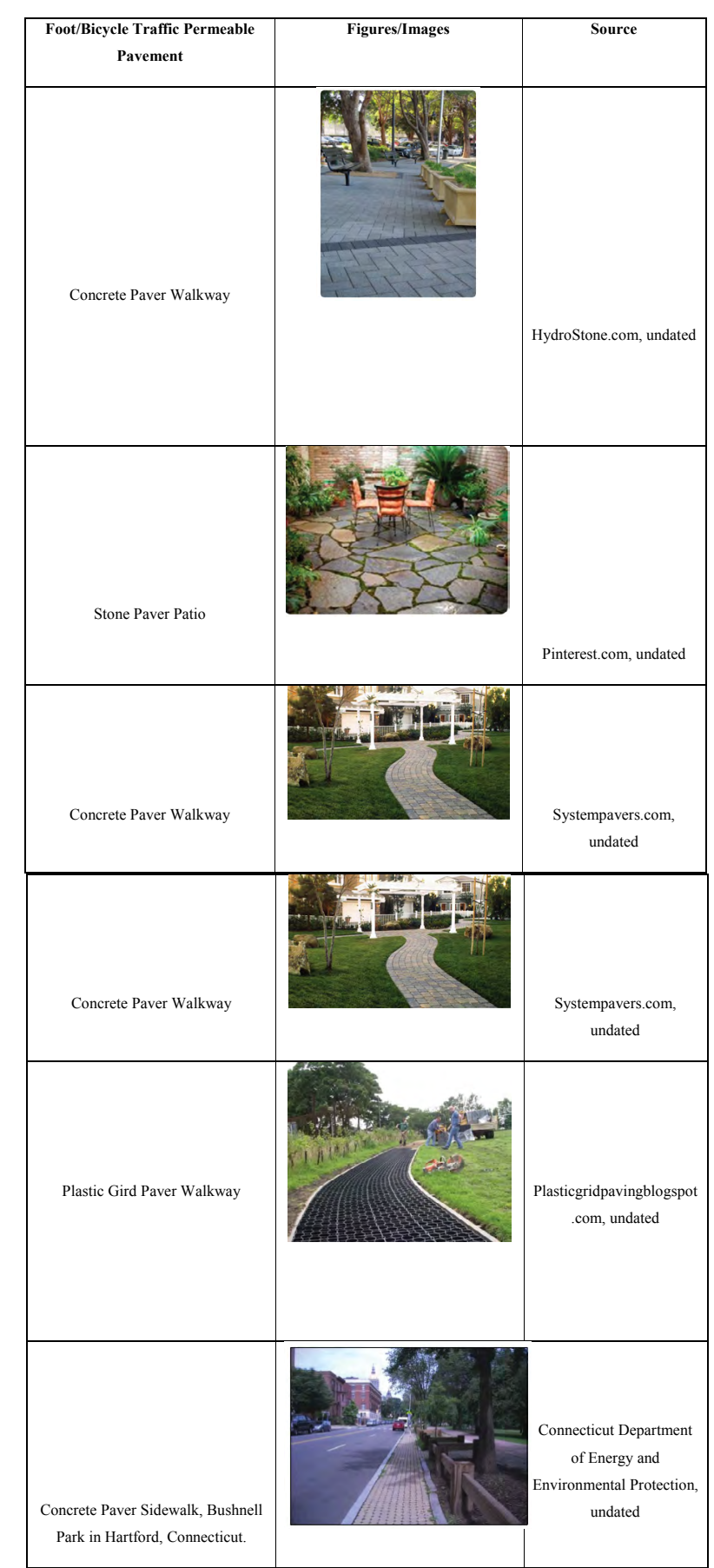

Figure 18: Examples of paver permeable pavement for foot and bicycle traffic.

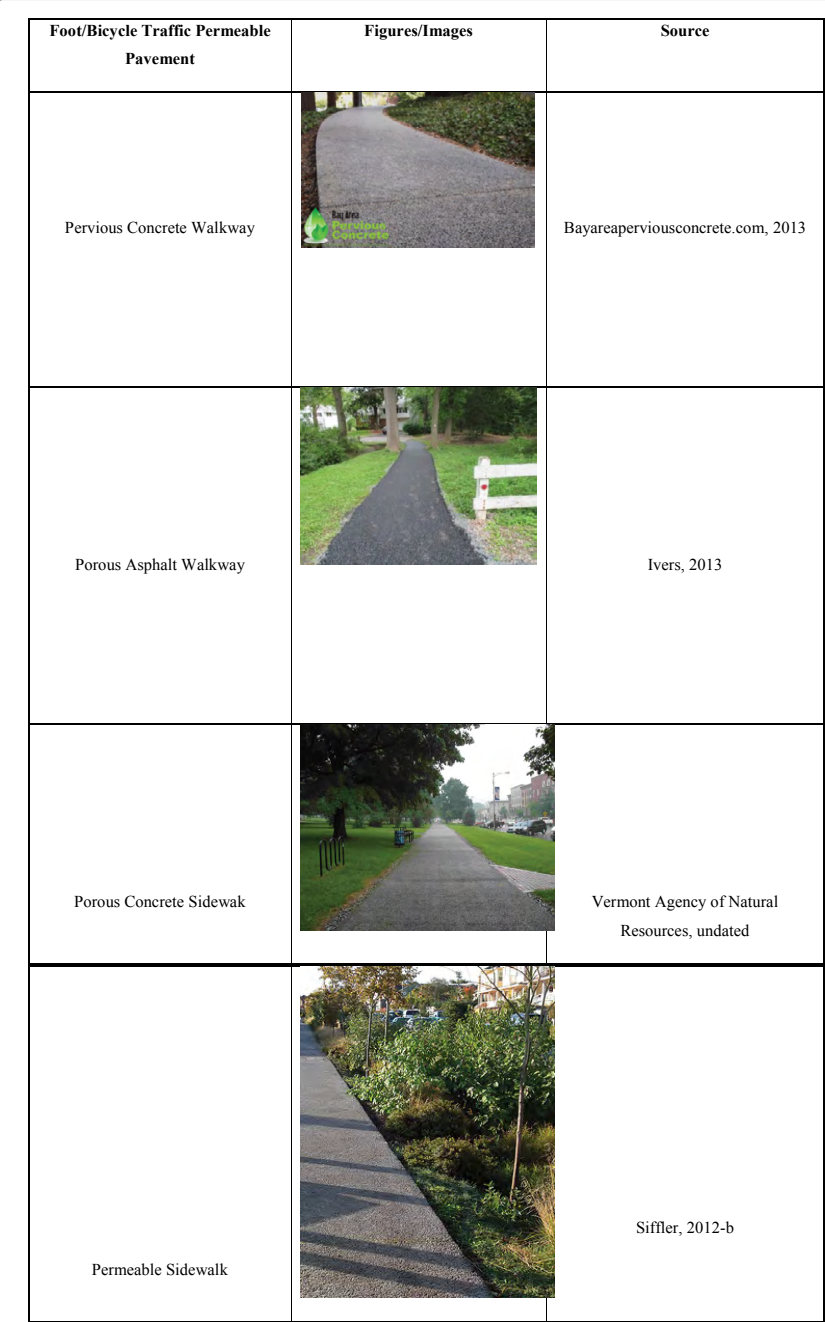

Figure 19: Examples of pervious concrete and porous asphalt permeable pavement for foot and bicycle traffic.

Some benefits of permeable friction course (PFC) as reported by the California Department of Transportation [47] and Stanard et al. [48] include: (a) water quality benefit, (b) rain condition skid resistance, (c) noise reduction as well as reduction in hydroplaning, splash and spray, raveling cracking and reflective cracking. In addition, National Asphalt Pavement Association [44], reports that the advantages gained from OGFC are: (a) reduced vehicle splash and spray behind vehicles, (b) enhanced visibility of pavement markings, (c) reduced nighttime surface glare in wet weather, and (d) reduced tire-pavement noise.

A survey of state departments of transportation (state DOTs) by Stanard et al. [48], showed that out of 47 state DOTs that responded to the survey, 17 (37\%) states were using PFC on a regular basis. Eight (17\%) state DOTs were testing PFC by evaluating test sections over certain time periods. The remaining $21(46 \%)$ state DOTs were not using or testing PFC at that time. Figure 24 shows a map of the states for each category according to their PFC use. The report by Stanard et al. [48] also shows that PFC is used in Europe.

Stanard et al. [48] also reported on pollutant removal by PFC in comparison to conventional impervious pavement (Table 14). Table 14 shows significant suspended solids (TSS) removal from road storm water by PFC which could be a major reason for clogging problem associated with PFC as the solids fills up the void spaces in the PFC. 


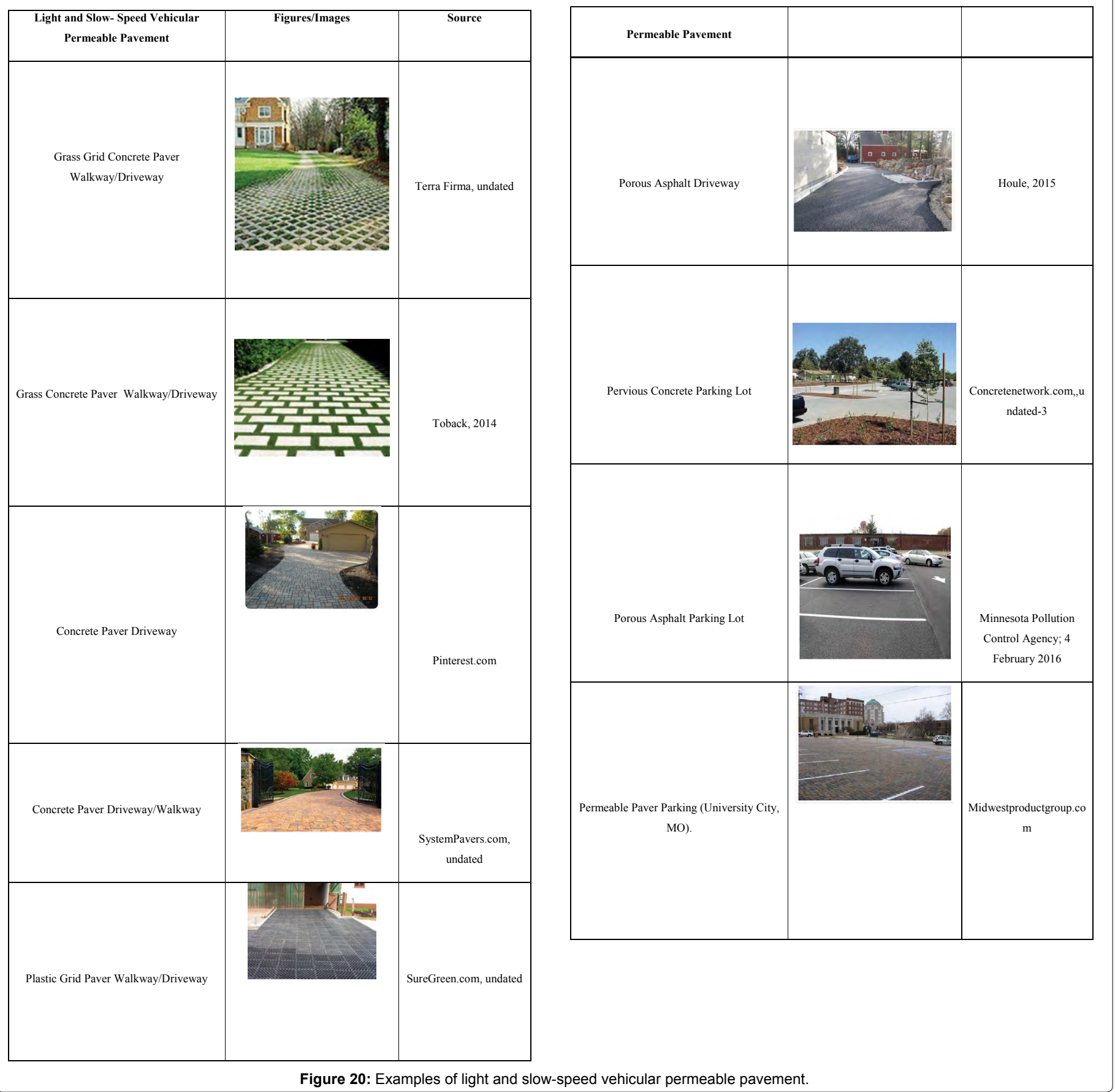

Table 14 shows significant reduction in pollutant concentrations in the highway storm water that is collected from pervious pavements in comparison to highway storm water that is collected from impervious pavement. Few test reports from Texas presented in Table 14 shows higher concentrations from pervious pavement, especially for low pollutant concentrations which could have been caused by difficulty in testing and analyzing samples with low initial pollutant concentration. The mechanisms responsible for the removal of the other pollutants listed in Table 14 were not reported and should be investigated.

\section{Permeable highway pavement and permeable highway shoulders}

The use of full-depth permeable pavement in highway environment where traffic includes high-speed and heavy vehicles is a recent advancement that is under investigation by various state department of transportation. AASHTO [33] presented conceptual permeable shoulder design (Figure 25). LakeSuperiorStreams.org (undated) has listed the use permeable pavements for road shoulders as one of the applications of permeable pavement. Kayhanian et al. [34] reported on test permeable asphalt and permeable concrete highways by Minnesota Department of Transportation. Houle [49] writes about successful application of porous asphalt for subdivision roads and highways.

The primary reason for the slow adoption of full-depth permeable pavement for highway environment is the issue of lack of strength to support fast and heavy traffic. Table 15 which present a summary of 


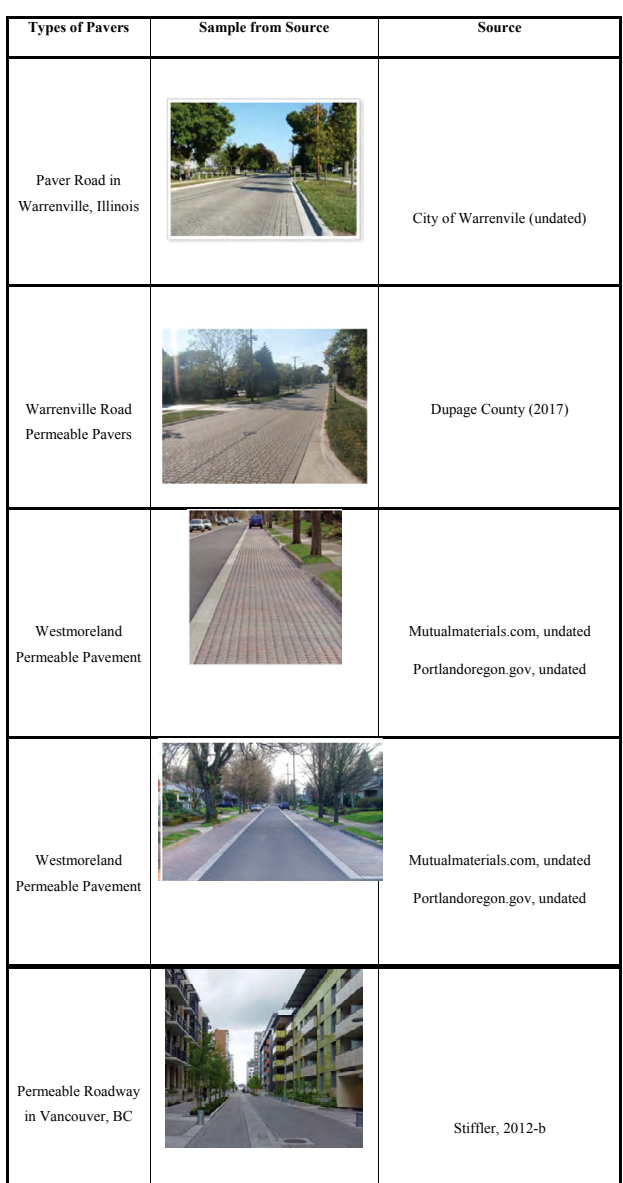

Figure 21: Examples of permeable paver residential streets (for light, slow speed traffic).

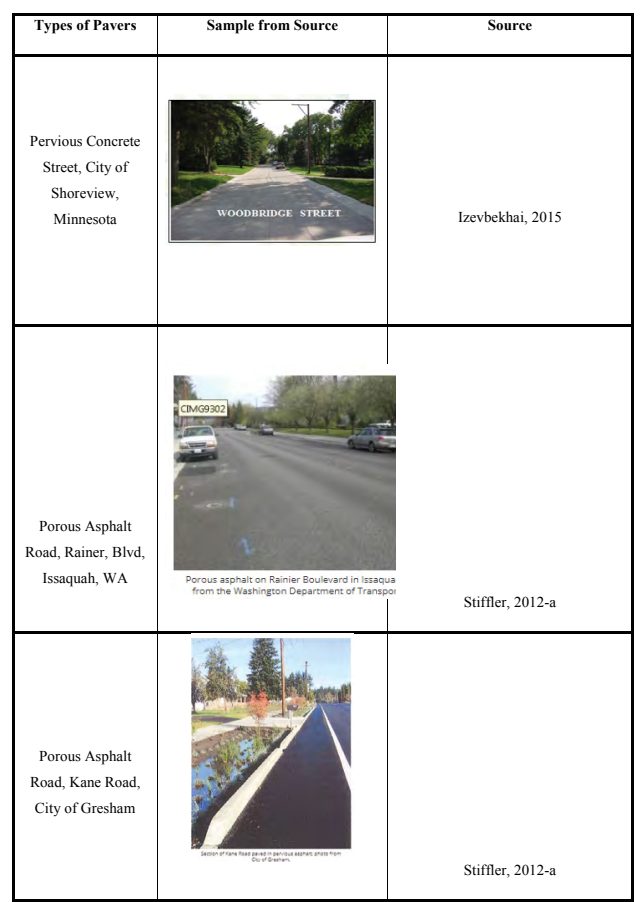

Figure 22: Examples of previous concrete and porous asphalt roads (for light, slow speed traffic).

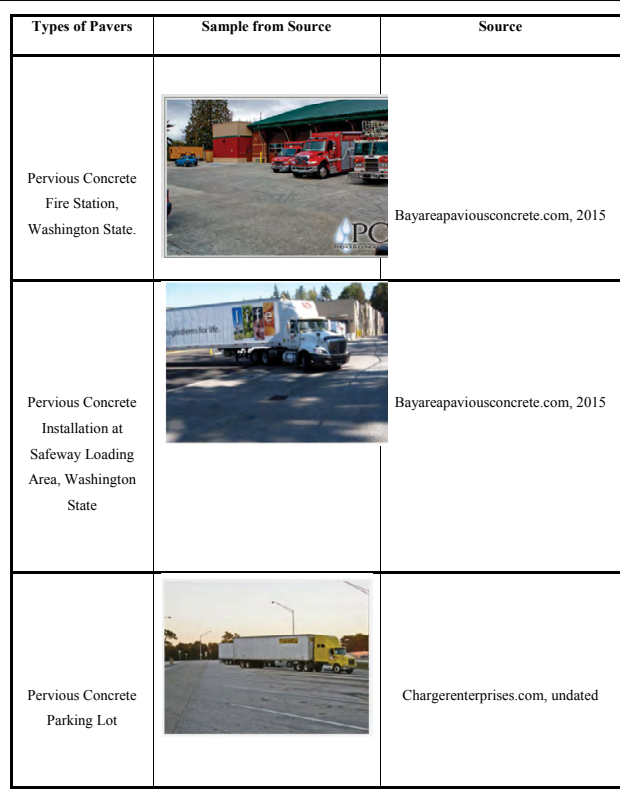

Figure 23: Examples of heavy, slow-speed vehicular permeable pavement.

\begin{tabular}{|c|c|c|c|c|c|c|}
\hline Location & $\begin{array}{c}\text { Age of Pave- } \\
\text { ment }\end{array}$ & $\begin{array}{c}\text { Flow } \\
\text { rate (Q) }\end{array}$ & $\begin{array}{c}\text { Hydraulic } \\
\text { Conductiv- } \\
\text { ity }\end{array}$ & $\begin{array}{c}\text { Void } \\
\text { Content }\end{array}$ & $\begin{array}{c}\text { Layer } \\
\text { Thick- } \\
\text { ness }\end{array}$ & $\begin{array}{c}\text { Max } \\
\text { Agg. } \\
\text { Size }\end{array}$ \\
\hline $\begin{array}{c}\text { Switzer- } \\
\text { land }\end{array}$ & Initial & $3.4 \mathrm{~L} / \mathrm{s}$ & - & $11-22 \%$ & $28-50 \mathrm{~mm}$ & $10 \mathrm{~mm}$ \\
\hline Spain & Initial & - & - & $>20 \%$ & $40 \mathrm{~mm}$ & $10 \mathrm{~mm}$ \\
\hline Belgium & Design Spec & $<1.4 \mathrm{~L} / \mathrm{s}$ & - & $19-25 \%$ & $40 \mathrm{~mm}$ & - \\
\hline Germany & 3 years & - & $17-40 \mathrm{~mm} / \mathrm{hr}$ & $19 \%$ & $40 \mathrm{~mm}$ & - \\
\hline $\begin{array}{c}\text { Nether- } \\
\text { lands }\end{array}$ & Design Spec & - & - & $>20 \%$ & $50 \mathrm{~mm}$ & $11 \mathrm{~mm}$ \\
\hline $\begin{array}{c}\text { Georgia } \\
\text { Design Spec }\end{array}$ & - & $100 \mathrm{~m} / \mathrm{day}$ & $10-20 \%$ & $30 \mathrm{~mm}$ & $\begin{array}{c}12.5 \\
\mathrm{~mm}\end{array}$ \\
\hline Florida & 2 months & & $1.2 \mathrm{~cm} / \mathrm{s}$ & - & $1.4 "$ & - \\
\hline Oregon & Design Spec & - & - & - & $50 \mathrm{~mm}$ & $19 \mathrm{~mm}$ \\
\hline Florida & Design Spec & - & $0.78 \mathrm{~cm} / \mathrm{s}$ & $18-22 \%$ & $32 \mathrm{~mm}$ & $10 \mathrm{~mm}$ \\
\hline
\end{tabular}

Table 13: PFC characterization data based on place of use [54].

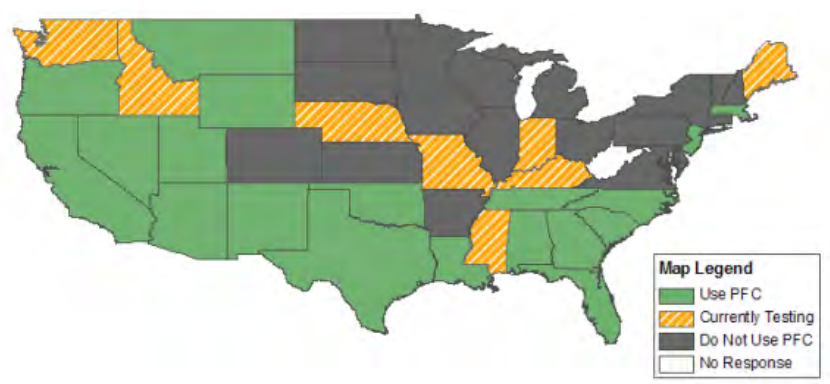

Figure 24: Survey results of P-FC use [48]

the benefits/advantages as well as limitations/disadvantages of porous concrete as reported by the U.S. Department of Transportation, Federal Highway Administration [50]. Limited use of permeable pavement in heavy traffic areas is the first limitation/disadvantages of permeable pavement listed in Table 15. Balancing the required strength of the pavement with the presence of voids, low compaction and water infiltration/storage is the challenge engineers must overcome for permeable pavement to be adopted in highway environment [51-58]. 


\begin{tabular}{|c|c|c|c|c|c|}
\hline Location & \multicolumn{4}{|c|}{ Pollutants and concentration from impervious and previous pavements } & \multirow[t]{2}{*}{ Sources } \\
\hline \multirow{9}{*}{ France } & Pollutants & Units & Impervious & Pervious & \\
\hline & Suspernded Solids & $\mathrm{mg} / \mathrm{L}$ & $153-354$ & $2-70$ & \multirow{8}{*}{ [49] } \\
\hline & Nitrogen, Kjeldahl & $\mathrm{mg} / \mathrm{L}$ & $2-3$ & $0.3-0.5$ & \\
\hline & Chemical Oxygen Demand & $\mathrm{mg} / \mathrm{L}$ & $143-149$ & $16-18$ & \\
\hline & Chlorine & $\mathrm{mg} / \mathrm{L}$ & $<1$ & $<1$ & \\
\hline & Copper & $\mu g / L$ & $91-163$ & $14-107$ & \\
\hline & Lead & $\mu g / L$ & $51-106$ & $2-22$ & \\
\hline & Zinc & $\mu g / L$ & $225-493$ & $18-133$ & \\
\hline & Cadmium & $\mu \mathrm{g} / \mathrm{L}$ & $0.8-0.9$ & 0.1 & \\
\hline \multirow{11}{*}{ France } & Pollutants & Units & Impervious & Pervious & \\
\hline & Suspernded Solids & $\mathrm{mg} / \mathrm{L}$ & 46 & 8.7 & \multirow{10}{*}{ [49] } \\
\hline & Nitrogen, Kjeldahl, Total & $\mathrm{mg} / \mathrm{L}$ & 2.1 & 1.2 & \\
\hline & Chemical Oxygen Demand & $\mathrm{mg} / \mathrm{L}$ & 80 & 80 & \\
\hline & NO3 & $\mathrm{mg} / \mathrm{L}$ & 6.7 & 2.1 & \\
\hline & Chlorine & $\mathrm{mg} / \mathrm{L}$ & 18 & 16 & \\
\hline & Hydrocarbons, Total & $\mathrm{mg} / \mathrm{L}$ & 1.2 & 0.09 & \\
\hline & Copper & $\mu g / L$ & 30 & 20 & \\
\hline & Lead & $\mu g / L$ & 40 & 8.7 & \\
\hline & Zinc & $\mu g / L$ & 228 & 77 & \\
\hline & Cadmium & $\mu g / L$ & 0.88 & 0.28 & \\
\hline \multirow{9}{*}{ Netherlands } & Pollutants & Units & Impervious & Pervious & \\
\hline & Suspernded Solids & $\mathrm{mg} / \mathrm{L}$ & $153-354$ & $2-70$ & \multirow{8}{*}{ [49] } \\
\hline & Nitrogen, Kjeldahl, Total & $\mathrm{mg} / \mathrm{L}$ & $2-3$ & $0.3-0.5$ & \\
\hline & Chemical Oxygen Demand & $\mathrm{mg} / \mathrm{L}$ & $143-149$ & $16-18$ & \\
\hline & Chlorine & $\mathrm{mg} / \mathrm{L}$ & $<1$ & $<1$ & \\
\hline & Copper & $\mu g / L$ & $91-163$ & $14-107$ & \\
\hline & Lead & $\mu g / L$ & $51-106$ & $2-22$ & \\
\hline & Zinc & $\mu g / L$ & $225-493$ & $18-133$ & \\
\hline & Cadmium & $\mu g / L$ & $0.8-0.9$ & 0.1 & \\
\hline \multirow{13}{*}{ Texas, USA } & Constituent & Conventional Asphalt & PFC & Reduction & \multirow{13}{*}{ [49] } \\
\hline & TSS (mg/L) & 117.8 & 9.7 & 92 & \\
\hline & TKN (mg/L) & 1.13 & 0.92 & 19 & \\
\hline & $\mathrm{NO}_{3} / \mathrm{NO}_{2}(\mathrm{mg} / \mathrm{L})$ & 0.43 & 0.5 & -16 & \\
\hline & Total P (mg/L) & 0.13 & 0.17 & -31 & \\
\hline & Dissolved P (mg/L) & 0.06 & 0.09 & -50 & \\
\hline & Total Copper & 26.8 & 13.1 & 51 & \\
\hline & Dissolved Copper & 5.9 & 10.3 & -75 & \\
\hline & Total Lead & 12.6 & $<1.3$ & 90 & \\
\hline & Dissolved Lead & $<1.0$ & $<1.0$ & NA & \\
\hline & Total Zinc & 167.4 & 43.2 & 74 & \\
\hline & Dissolved Zinc & 47.1 & 35.9 & 24 & \\
\hline & COD (mg/L) & 64 & 55 & 14 & \\
\hline
\end{tabular}

Table 14: Storm water pollution control benefit of permeable pavement.

\section{Discussion}

Accumulation of storm water on road surfaces results in various forms of pavement damage reduces skid resistance (friction coefficient) of pavements, causes hydroplaning, results in plash and spray of road water all of which lead to car crashes, injuries and fatalities [59-64]. Draining of storm water from road surfaces is critical for the provision of dry pavement surfaces with associated skid resistance for the safety of the traveling public as well as for enhancing pavement durability [65-70]. Engineers have used road design methodology and drainage systems to remove storm water from the surface of impervious pavements [71-74]. Alternatively, permeable pavement has been found to offer sustainable storm water management option $[75,76]$.

There are three major types of permeable pavement, namely; permeable pavers, pervious concrete pavement, and porous asphalt pavement [77-81]. Permeable pavers include: (a) interlocking concrete pavers, (b) brick pavers, (c) stone pavers, (d) Grass/turf pavers, (e) grid concrete pavers, and (f) grid plastic pavers. With the different types of permeable paving materials and the use of the words "pervious" "porous", and "permeable", it is difficult to know the exact type of permeable pavement from title of a report or a publication on the subject. For example, some literature tend to use the phrase "porous pavement" to refer to permeable asphalt pavement and the phrase "pervious pavement" to refer to permeable concrete pavement [8285]. Also, it is common to find "pavers" being referred to as permeable pavement without the word "paver". The author recommends adding the name of the paving material (asphalt, concrete, pavers) to the word "permeable", porous, or pervious to eliminate or reduce the confusion associated with current naming of permeable pavement. The author recommends the following naming system: (1) permeable pavers or pervious pavers or porous pavers, (2) permeable concrete or pervious concrete or porous concrete and (3) permeable asphalt, or pervious asphalt or porous asphalt. 


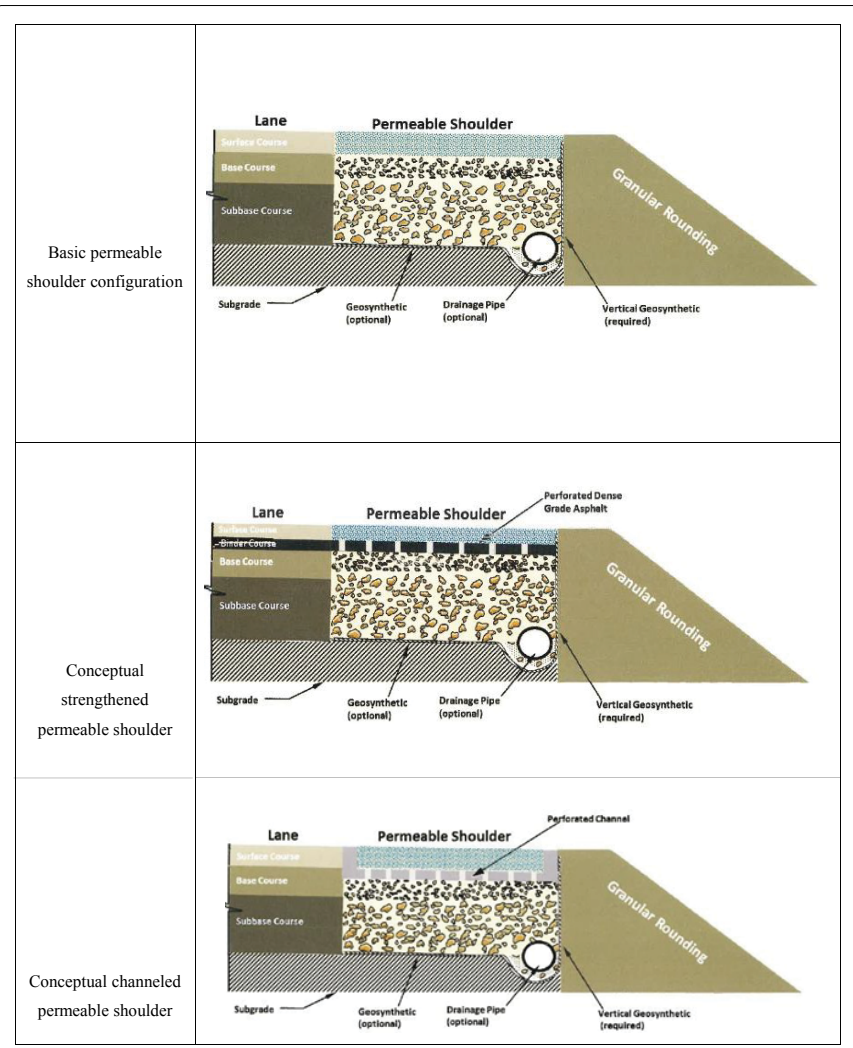

Figure 25: Conceptual permeable shoulder designs [39].

\begin{tabular}{|c|c|c|}
\hline SL. & Benefits/Advantages & $\begin{array}{c}\text { Limitations/ } \\
\text { Disadvantages }\end{array}$ \\
\hline 1 & $\begin{array}{c}\text { Effective management of stormwater runoff, } \\
\text { which may reduce the need for curbs and } \\
\text { the number and sizes of storm sewers. }\end{array}$ & $\begin{array}{c}\text { Limited use in heavy vehicle } \\
\text { traffic areas. }\end{array}$ \\
\hline 2 & Reduced contamination in waterways. & $\begin{array}{c}\text { Specialized construction } \\
\text { practices. }\end{array}$ \\
\hline 3 & Recharging of groundwater supplies. & Extended curing time, \\
\hline 4 & $\begin{array}{c}\text { More efficient land use by eliminating need } \\
\text { for retention ponds and swales. }\end{array}$ & $\begin{array}{c}\text { Sensitive to water content } \\
\text { and control in fresh } \\
\text { concrete. }\end{array}$ \\
\hline 5 & $\begin{array}{c}\text { Reducing heat island effect (due to } \\
\text { evaporative cooling effect of water and } \\
\text { convective airflow. }\end{array}$ & $\begin{array}{c}\text { Lack of standardized test } \\
\text { methods. }\end{array}$ \\
\hline 6 & $\begin{array}{c}\text { Elimination of surface ponding of water and } \\
\text { hydroplaning potential }\end{array}$ & $\begin{array}{c}\text { Special attention and care } \\
\text { in design of some soil types } \\
\text { such as expansive soils and } \\
\text { frost-susceptible ones. }\end{array}$ \\
\hline 7 & $\begin{array}{c}\text { Reduced noise emissions caused by tire- } \\
\text { pavement interaction }\end{array}$ & $\begin{array}{c}\text { Special attention possibly } \\
\text { required with high } \\
\text { groundwater. }\end{array}$ \\
\hline 8 & Earned LEED credit & - -- \\
\hline
\end{tabular}

Table 15: Benefits/advantages as well as limitations/disadvantages of porous concrete [57].

Advancement in the design of permeable pavement has led to various applications including: (1) installations for foot and bicycle traffic such as walkways, sidewalks, driveways, parking areas, alleys, patios, courtyards, and pedestrian plazas; (2) installations for slowspeed, light vehicle traffic such as parking lots and residential streets, and (3) installations for slow-speed, heavy vehicle traffic parking lots. In addition, Porous Friction Course (PFC), also known as OpenGraded Friction Course (OGFC) has been used in high-speed highways for both light and heavy vehicle traffics [86-89]. PFC is a thin layer of porous Hot-Mix Asphalt (HMA) surface overlay placed on top of impervious pavement where storm water infiltrates the thin layer of the PFC and moves laterally on top of the impervious layer towards the road shoulder at where it is collected and piped for treatment.

Permeable pavements provides sustainable best management practice for roadway storm water by allowing roadway storm water to infiltrate and self-drain into the pavement where it can either flow into the underlying soil or get collected for treatment and thus reduces the concentration of pollutants in the water that passes through its structural layers [90-97]. It also reduces noise that results from the interaction of vehicle tires and pervious surfaces. In addition, by removing water from the road surfaces, permeable pavement provides safety to the travelling public. Infiltration of water into and through permeable pavement is made possible because of the presence of voids in pavement structure along with limited compaction. In addition, some permeable pavements are installed with storm water reservoir layer. While the structural nature of permeable pavement provides storm water infiltration benefits, it also has impact on the strength needed for its installation in highways. However, the use of permeable pavement for highways and for highway shoulders is being investigated by engineers.

\section{Conclusion}

In conclusion, the author identifies the following research needs to further enhance the use of permeable pavement:

1. The mechanisms responsible for the removal of pollutants by permeable pavement should be investigated as well as clogging of the voids by solids, long term pollution removal efficiency and the need for replacement of layer materials and/or need for vacuuming the pavement.

2. Appropriate permeable pavement structures that has the required structural strength to serve in highway environments while providing its intended safety functions.

3. Impact of storm water infiltration on the stability road sideslopes and safe-use of road clear recovery zone (CRZ)

4. Test data on effect of compaction on the strength (stability) and infiltration of permeable shoulders and road side-slopes is needed.

5. Test data on the impact of stabilization and reinforcement on the strength (stability) and infiltration of permeable shoulders and road side-slopes.

\section{Acknowledgements}

The article was supported in part by a grant from Mineta Transportation Institute (MTI). The author would like to thank Professor Akthem Al-Manaseer for his review of the work associated with the MTI project. The author sincerely thanks MTI Executive Director Karen Philbrick, Ph.D,; Publication Support Manager Joseph Mercado; and Editor and Webmaster Frances Cherman. The content of this article reflect the view of the author who is responsible for the contents of this publication.

\section{References}

1. U.S. Department of Transportation, Federal Highway Administration (2000) Stormwater best management practices in an ultra-urban setting: selection and monitoring.

2. Walsh CJ, Fletcher TD, Burns MJ (2012) Urban storm water runoff: A new class of environmental flow problem. PLoS One 7: e45814.

3. Dawson A (June 2007) Water movement in road pavements and embankments

4. U. S. Environmental Protection Agency (2016) National pollution discharge elimination system (npdes): storm water discharges from transportation sources. 
Citation: Ndon UJ (2017) Trends in the Application of Permeable Pavement as Sustainable Highway Storm Water Management Option for Safe-Use of Roadways. J Civil Environ Eng 7: 288. doi: 10.4172/2165-784X.1000288

5. California Department of Transportation (2004) BMP retrofit pilot program

6. Pennsylvania Department of Environmental Protection (2006) Pennsylvania storm water best management practices-Manual.

7. Transportation Research Board (2006) Evaluation of best management practices for highway runoff control. NCHRP Report 565.

8. Texas Transportation Institute (2009) Storm water treatment with vegetated buffers.

9. California Department of Transportation (2010) Treatment BMP technology report.

10. Virginia Asphalt Association (2000) Parking lot design.

11. Reid JM, Crabb GI, Temporal J, Clark M (2006) A study of water movement in road pavements. Transportation Research Foundation Project Report PPR082. TRL Limited.

12. Sandy B (2000) Proper drainage ensures lasting asphalt pavement structures. Asphalt Magazine.

13. Fwa TF (1987) Water-induced distress in flexible pavement in a wet tropical climate. Transp Res Rec 1121: 57-65.

14. Kandhal P, Prithvi S, Lubold Jr, Carl W, Roberts FL (1989) Water damage to asphalt overlays: Case history. National Center for Asphalt Technology, Nashville, Tennessee, USA.

15. Hu J, Wang X, Rendong G (2011) Rainfall infiltration influence to asphalt pavement Communications in Computer and Information Science 175: 170-173.

16. Pavement Interactive (2006) Blowup.

17. Pavement Interactive (2008) Drainage.

18. Pavement Interactive (2009) Pumping.

19. Asphalt Institute (2000). Asphalt pavement distress summary.

20. Yilmaz A, Sargin S (2012) Water effect on deterioration of asphalt pavements Online $\mathrm{J}$ of Sci and Tech 2:1.

21. Pavement Interactive (2013) Let it drain - Protecting roads from moisture damage.

22. California Department of Transportation (2000). Common distresses on rigid pavements.

23. California Department of Transportation (2001) Common distresses on flexible pavements.

24. California Department of Transportation (2008) Flexible pavement preservation (2nd edn): Introduction. MTAG Volume I.

25. Suryakanta $P$ (2016) 5 Forms of failures in rigid pavement. civilblog.org.

26. Pavement Interactive (2000) Rigid pavement distress.

27. Pavement Interactive (2001) Flexible pavement distress.

28. Brett N (2000) 13 pavement defects and failures you should know.

29. Ndon UJ, Al-Manaseer A (2017) Permeable pavement as a sustainable management option for highway storm-water and safe use of roadways. Seed Project Report Submitted to Mineta Transportation Institute. College of Business, San Jose State Univeristy, San Jose, CA 95192-0219, USA

30. U.S. Department of Transportation, Federal Highway Administration (2016) How do weather events impact roads?.

31. Greg L (2015) Dangers of splash and spray of accumulated storm water on road surfaces.

32. Wilson DJ (2013) The effect of rainfall and contaminants on road pavement skid resistance. New Zealand Transport Agency Research Report 515.

33. Do MT, Cerezo V, Zahouani H (2014) Laboratory test to evaluate the effect of contaminants on road skid resistance. Proc Inst Mech Eng J Eng Tribol 228:1276-1284.

34. Road Traffic Signs (2000) Slippery road signs and icy road warnings.

35. Glennon JC (2015) Roadway hydropalning - A framework to determine critical pavement wheel rut depth.

36. Virginia Department of Transportation (2005) Section A-1-Geometric Design Standard.
37. County Engineering-Sacramento (2009) Section 4 Streets.

38. About civil.org (2000) Typical cross-section of highways roadways, aboutcivil.com

39. Hein DK, Strecker E, Poresky A, Roseen R, Venner M (2013) Permeable shoulders with stone reservoirs. AASHTO

40. Kayhanian M, Weiss P, Gulliver J, Lev K (2015) The application of permeable pavements in highways and urban roads. National Center for Sustainable Transportation, USA.

41. Walker M (2013) Are pervious, permeable, and porous pavers really the same? Storm water Report, Water Environment Federation, Virginia, USA.

42. North Inlet-Winyah Bay National Estuarine Research Reserves (2014) Low impact development in coastal, A Planning and Design Guide, South Carolina, USA

43. Minnesota Pollution Control Agency (2016) Types of permeable pavement.

44. Minnesota Pollution Control Agency (2016) Permeable Pavement.

45. Concretenetwork.com (2000) How pervious concrete works.

46. Concretenetwork.com (2001) Ten strategies for ensuring a successful pervious concrete installation.

47. Minnesota Department of Natural Resources (2003). Permeable pavement: Asphalt, concrete, or pavers.

48. Virginia Department of Environmental Quality (2011) Permeable pavement, Version 1.8

49. California Department of Transportation (2014) Pervious pavement design guide.

50. National Asphalt Pavement Association (2002) Design, construction, and maintenance of open-graded asphalt friction course.

51. Pavement Interaction (2011) Open-graded friction courses-keeping an open mind.

52. Ephenryecocenter.com (2000) Adapting full-depth permeable pavement fo highway shoulders and urban roads for storm-water runoff management.

53. California Department of Transportation (2006) Open-graded friction course usage guide.

54. Stanard C, Canadaele R, Charbeneau R, Barrett M (2007) State of the practice: Permeable friction courses.

55. Lakesuperiorstreams.org (2000) Pervious pavement

56. Houle K (2015) Advocating for responsible stewardship of land and natura resources in landscaping and horticulture practices: Permeable solutions for sloped surfaces; A case study.

57. U.S. Department of Transportation, Federal Highway Administration (2012) Tech Brief: Pervious concrete.

58. About Civil.org (2000) Typical cross-section of highways roadways.

59. American Concrete Pavement Association (2006) Pervious concrete pavement: Storm water management with pervious concrete pavement.

60. Angeluspavingstones.com (2001) Paver systems: Turfstone grid pavers.

61. Barrett ME (2001) Storm water quality benefits of a permeable friction course. Center for Research in Water Resources, PRC \#119, University of Texas, USA.

62. Bayareapaviousconcrete.com (2015) Pervious concrete has been supporting heavy loads. Tire abrasion and freeze-Thaw cycles for years.

63. Bayareaperviousconcrete.com (2013) UC Berkeley's Newest Path is Pervious: November 01, 2013 in Commercial, Sidewalk or Path Installation.

64. Bean EZ, Hunt WF, Bidelspach DA (2004) Study on the Surface infiltration rate of permeable pavements.

65. Chargerenterprises.com (2000) Pervious concrete: Is pervious concrete strong enough.

66. City of Warrenville (2001) Permeable Pavement.

67. Concretenetwork.com (2002) Pervious concrete pavements.

68. Connecticut Department of Energy and Environmental Protection (2000). A resident's guide to pervious pavement. Connecticut, USA.

69. Andrew D (June 2007) Water movement in road pavements and embankments

70. Dupage County (2017) Warrenville road permeable paver reconstruction. The county of dupage Wheaton, Illinois. 
Citation: Ndon UJ (2017) Trends in the Application of Permeable Pavement as Sustainable Highway Storm Water Management Option for Safe-Use of Roadways. J Civil Environ Eng 7: 288. doi: 10.4172/2165-784X.1000288

71. Hawaii Asphalt Paving Industry (2000) Sample porous asphalt.

72. Huffman D (2000) Pervious pavement: An infiltration BMP - A LID technique.

73. Hydrostone.com (2001) Paver Walkway.

74. Ivers M (2013) Chatham borough constructs a new sidewalk and paves pathways with porous asphalt.

75. Izevbekhai B (2015) Pervious concrete at the MN road low volume road.

76. Midwestproductsgroup.com (2010) Permeable Paver Parking, University City, MO, USA.

77. Minnesota Pollution Control Agency (2016) Permeable pavement.

78. Mutualmaterials.com (2000). Permeable Pavement Pilot Project: Westmoreland Permeable Pavement Pilot Project; Streets and Parking Lots. Portland, Oregon, USA.

79. National Association of City Transportation Officials (2004) New Jersey storm water best management practices Manual Chapter 9.7: Standard for Pervious Paving Systems.

80. Paylesshardwareandrockery.com (2000) Pavers and retaining walls in San Jose, USA.

81. Perviouspavement.org (2000) Pervious pavement: Pervious concrete pavement.

82. Pinterest.com (2000) Paver stones.

83. Plasticgridpavingblogspot.com (2000) Plastic grid paving.
84. Reid JM, Crabb GI, Temporal J, Clark M (2006) A study of water movement in road pavements. Transportation Research Foundation Project Report PPR082. TRL Limited.

85. Road Traffic Signs (2000) Slippery road signs and icy road warnings.

86. SC Waterways (2013) An introduction to porous pavement.

87. Southbaymaterials.com (2000) Bricks and decorative rocks in San Jose, USA.

88. Stiffler L (2012a) Surprisingly ambitious permeable products: Northwest engineers reach beyond their permeable pavement comfort zones.

89. Stiffler $L$ (2012b) Promise of permeable pavement: Separating the facts and fears around permeable pavement.

90. Suregreen.com (2000) Reinforced concrete grid paver.

91. Systempavers.com (2000) Why Interlocking Pavers?

92. Terra Firma GRC and Concrete Industries (2000) Grass Grid Pavers.

93. Toback R (2014) Grass driveway with permeable pavers.

94. U.S. Department of Transportation, Federal Highway Administration (2009) Maintenance of drainage features for safety.

95. U.S. Department of Transportation, Federal Highway Administration (2015) Porous asphalt pavements with stone reservoirs.

96. Vermont Agency of Natural Resources (2000) Low impact development practice: Porous pavement.

97. Worldhighways.com (2012) Japanese dual layer paving technology 